\title{
Catalytic Production of Levulinic Acid (LA) from Actual Biomass
}

\author{
Michela Signoretto ${ }^{\circledR}$, Somayeh Taghavi, Elena Ghedini and Federica Menegazzo * \\ CATMAT Lab, Department of Molecular Sciences and Nanosystems, \\ Ca' Foscari University of Venice and INSTM RUVe, via Torino 155, 30172 Venezia Mestre, Italy \\ * Correspondence: fmenegaz@unive.it
}

Received: 28 June 2019; Accepted: 26 July 2019; Published: 30 July 2019

\begin{abstract}
Catalytic conversion of actual biomass to valuable chemicals is a crucial issue in green chemistry. This review discusses on the recent approach in the levulinic acid (LA) formation from three prominent generations of biomasses. Our paper highlights the impact of the nature of different types of biomass and their complex structure and impurities, different groups of catalyst, solvents, and reaction system, and condition and all related pros and cons for this process.
\end{abstract}

Keywords: three generations of biomasses; actual biomass transformation; hydrolysis; levulinic acid; catalysts; biorefinery

\section{Introduction}

Among the challenging issues that humans are struggling with in the 21st century, Climate change and Energy security are considered as the most important issues that need to be addressed [1]. With the rapid depletion of fossil fuels, international attempt to raise the use of renewable energy such as biomass has greatly increased [2-4]. Various approaches, including thermal, biological, and chemo-catalytic processes have been performed in order to produce fuels and chemicals from biomass, owing to environmental and economic needs [5]. Two different types of processes are used for this application. The first type is thermochemical process in which the entire biomass could be considered as feedstock. These processes mainly include gasification, liquefaction, pyrolysis, and high-pressure supercritical extraction. On the other hand, individual fractions of biomass, including starch, sugars, cellulose, and fatty acids could be separated and transformed by a hydrolysis step (catalyzed by acids or bases), after which there are several processes for transforming each one [6]. Acid-catalyzed hydrolysis has been considered to be a crucial step for chemicals production at a relatively mild temperature $\left(100-250^{\circ} \mathrm{C}\right)$. Furfural, glucose, 5-hydroxymethylfurfural (5-HMF), and levulinic acid (LA) are regarded as the key intermediate platform chemicals [7].

LA is a linear C5-alkyl carbon chain that is known as 4-oxopentanoic acid or gamma ketovaleric acid and also 3-acetylpropionic acid. It is a short chain fatty acid with molecular formula $\mathrm{C}_{5} \mathrm{H}_{8} \mathrm{O}_{3}$ (see Figure 1) [8]. The Biomass Program of the US Department of Energy in 2004 regarded LA as one of the top 12 most promising bio-based platform chemicals [2].

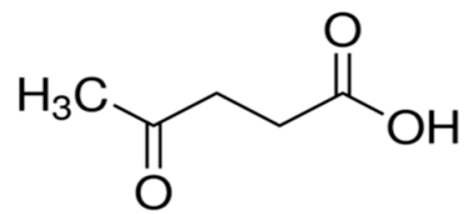

Figure 1. The molecular structure of levulinic acid. 
LA acts as a viable chemical bridge between biomass and petroleum processing. Multiple LA derivatives have been suggested for fuel applications, such as $\gamma$-valerolactone (GVL), ethyl levulinate (EL), and methyl tetrahydrofuran (MTHF). One of the most important processes is the hydrogenation of LA to $\gamma$-valerolactone, and further to liquid alkenes with eight or more carbons. In addition, LA can be used as a as gasoline and biodiesel additives by conversion to a family of valerate esters [9-17]. Besides renewable biofuels, LA is also a promising basic chemical for other applications. As shown in Figure 2, LA can be converted to a range of multiple derivatives that have various market applications. The chemicals that are produced from LA are currently used in several industries, such as solvents, resins, chemical intermediates, polymers, electronics, batteries, adsorbents, photography, plasticizers rubber, cosmetic, drug delivery systems, textiles, and pharmaceutical products [7,8,18-29].

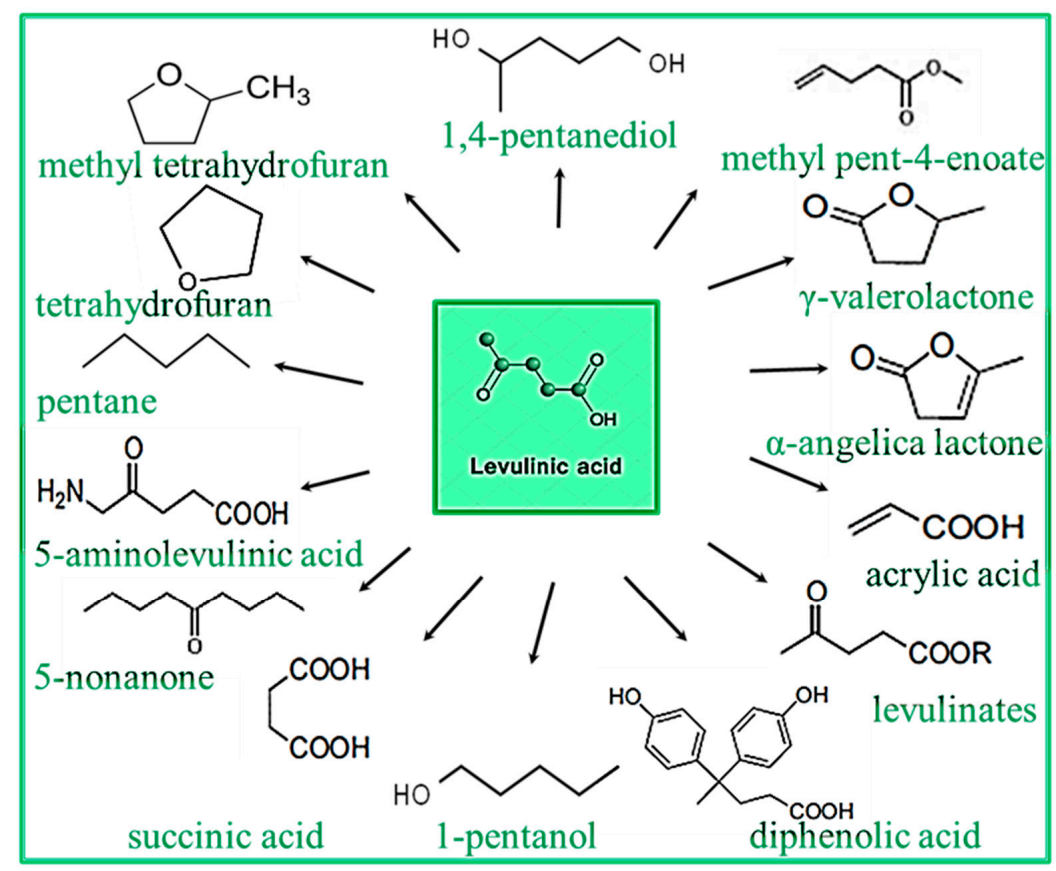

Figure 2. Levulinic acid (LA) derivatives $[1,17]$.

There are several different feedstocks for synthesis of LA, including raw materials and precursors, such as polysaccharides, monosaccharides, furfural, 5-hydroxymethyl furfural (5-HMF), and renewable resources, such as the most types of biomasses. Polysaccharides, including starch, cellulose, hemicellulose, and chitin, are the main components of biomass. Their hydrolysis could lead to the formation of monosaccharides, such as glucose and fructose [30].

As can be seen in Figure 3, there are three different generations of biomasses:

(i) First generation of biomass comes from food crops such as sugar, starchy crops, vegetable oil, or animal fat.

(ii) Second generation of biomass is non-food crops such as wood, organic waste, food crop waste, and specific biomass crops. Most of biomasses in this generation are considered as the lignocellulosic biomass.

(iii) Third generation of biomass comes from algae.

Therefore, the reaction of LA production from three different generations of biomass is consecutive and usually includes three general steps (see Figure 3):

(i) pretreatment of biomass to extract polysaccharides,

(ii) hydrolysis of polysaccharides into monosaccharides such as hexoses and pentoses, and pentoses,

(iii) conversion of monosaccharides to LA during several steps [31]. 
The pretreatment of biomass is a compulsory and significant step in its transformation to LA in order to have a great LA yield and reaction rates since the structure of raw biomass is very complex. Moreover, the type and severity of pretreatment could be of crucial importance, according to the complexity of the raw starting biomass [32]. The next important route is several steps acid catalyzed reaction for formation of $L A$ from different types of $C_{5}$ and $C_{6}$ sugars, which can also drive from the hydrolysis of polysaccharides or more complex carbohydrates extracted from pretreatment of raw biomass, such as cellulose, hemicellulose or starch. For these reactions the acidity of the catalyst plays a crucial role in which both Lewis and Brønsted acid sites in catalyst and great balance of them are highly needed.

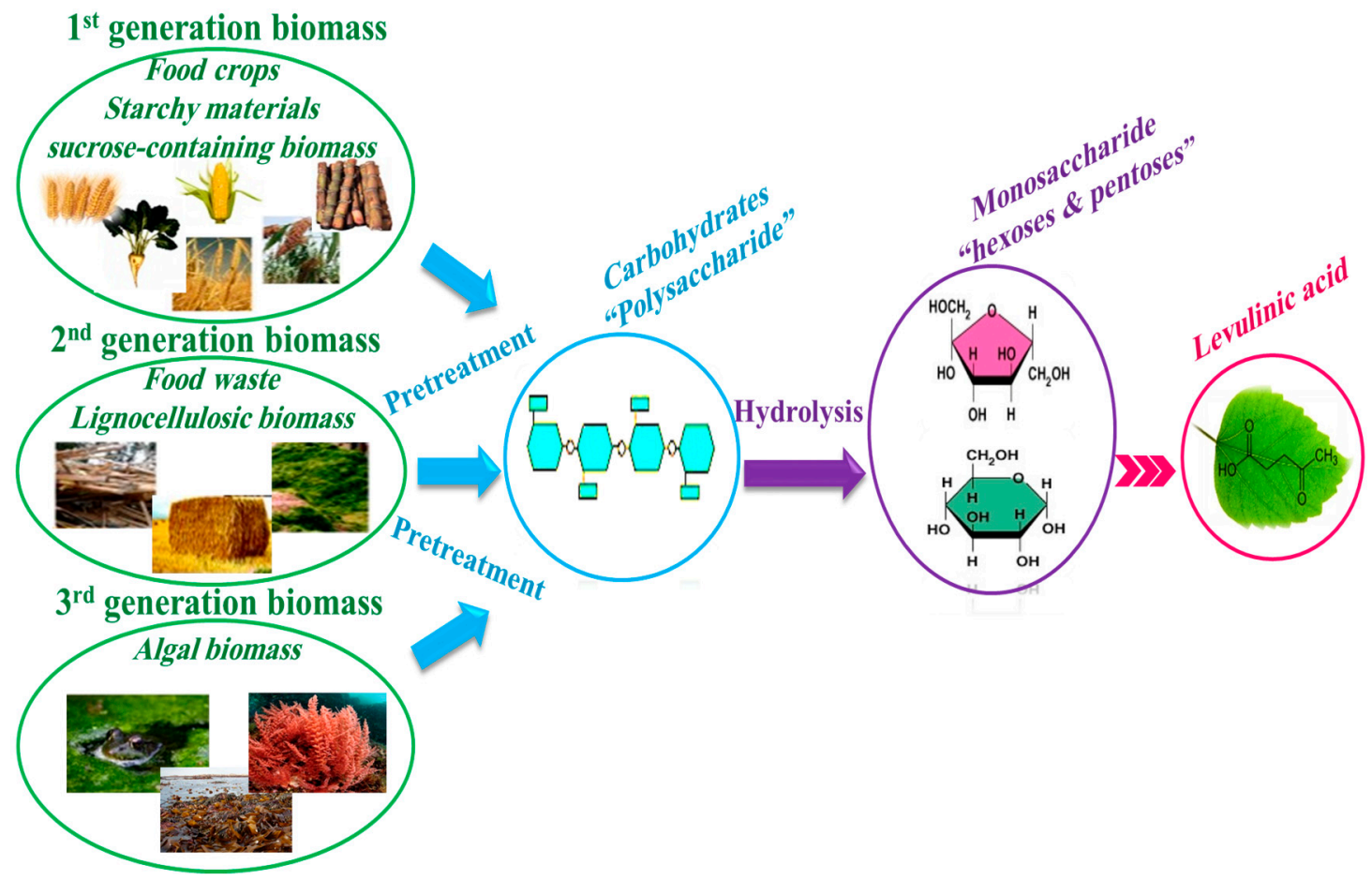

Figure 3. Roadmap of LA production from biomass.

Although several researches have been undertaken on the tailored acid catalyzed hydrolysis of biomass, and this interest continues to rise in the recent years, few review papers have been published regarding the synthesis of LA from real biomass, especially focusing on using three different generation of biomasses as a feedstock, including starchy, lignosellulosic, and marine biomasses [4,33,34]. Thus, in this review, we focus on different biomass categories and using catalysts in the real biomass conversion and the production of one of the valuable chemical, named LA, based on recent years' studies.

\section{LA Production from First Generation of Biomass: Starchy and Sugary Biomass}

First generation of biomass consisting starchy and sugary biomass can be converted to LA during several steps (see Figure 4): (1) the hydrolysis of starch or sugar as a polysaccharide to glucose catalyzed by a Brønsted acid; (2) isomerization of glucose to fructose by using a Lewis acid; (3) dehydration of fructose to 5-HMF catalyzed by bifunctional acid; and, (4) rehydration of 5-HMF to LA catalyzed by Brønsted acid. It was demonstrated that the conversion pathway of glucose to 5-HMF depends on the type of the catalyst. It has been established that fructose can only be formed as an intermediate when Lewis acid catalysts are used in this reaction considering that not all Lewis acid sites are active for glucose isomerization, but they simultaneously act as a catalyst for side reaction or soluble polymers and insoluble humins. On the other hand, if a strong Brønsted acid has catalyzed the reaction, glucose 
dehydration follows a route with 3-deoxy-glucosone as an intermediate [35-37]. Therefore, there are several reaction networks happening through transformation of biomass to LA: (1) isomerization of glucose to fructose, which dehydrates to HMF and rehydrates to LA and formic acid; (2) direct dehydration of glucose to HMF; (3) direct dehydration of glucose to furfuryl alcohol which converts to LA and byproducts; and, (4) side reaction of glucose, fructose, HMF, and furfuryl alcohol, which leads to the production of byproducts, especially tarry humins and char-byproducts. Different types of techniques are suggested to prevent side reactions by controlling the process significant parameters, such as acidity, pressure, temperature, pressure, reaction time, and conducting in situ extraction since the structure of biomass is very complex. Additionally, all these side reactions are probable in transformation of second and third generations of biomass.

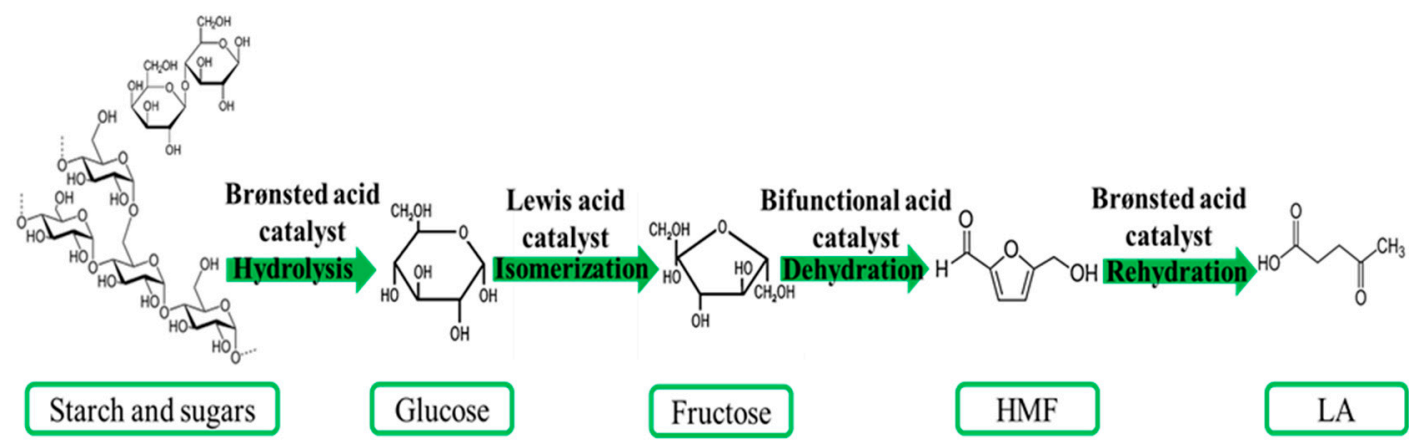

Figure 4. Overview of LA production from first generation biomass.

As shown in Table 1, in the last few years, there are few researches that focus on and using first generation biomass in order to produce biochemical. In all of these works, homogenous catalysts were used for hydrolysis process.

In 2016, a paper reported LA production from three different corn starches, including normal corn starch, high-amylose corn starch, and waxy corn starch while using both microwave and conventional oil bath heating [38]. For both methods, water was used as the solvent and $\mathrm{HCl}$ was preferred as the catalyst rather than other mineral acid catalysts because the authors claimed that $\mathrm{HCl}$ can be more effective for LA production. In addition, temperatures of $135,150,165$, and $180{ }^{\circ} \mathrm{C}$ were set and a hold time of $0,5,10$, or $15 \mathrm{~min}$. was applied to the runs. In microwave heating method, the LA yield for waxy corn starch in the shorter reaction time (0 and $5 \mathrm{~min}$.) were the highest one while there were a very slight differences at higher reaction times and temperatures concluding that the lower equivalent temperatures and shorter reaction times could be considered for microwave heating. Anyway, the maximum yield of LA was around 53-55\% for all substrates and for both heating media at optimum temperature of $165^{\circ} \mathrm{C}$ and time of $15 \mathrm{~min}$. Microwave- assisted heating can be used as a more effective heating method than traditional ones. The use of microwave heating causes a homogeneous heat transfer into the biomass feedstock by dipole rotation and ionic conduction using less energy when compared to the traditional heating method. Hence, microwave reactor results a significant time and energy saving [39].

In 2002, kernel sorghum grain was transferred to LA by using aqueous solution of $\mathrm{H}_{2} \mathrm{SO}_{4}$ as the catalyst. The reaction was performed in several conditions, including different $\mathrm{H}_{2} \mathrm{SO}_{4}$ concentration, sorghum flour loading, and temperature. The yield of LA was increased with the decrease of the sorghum flour loading and increase of temperature and $\mathrm{H}_{2} \mathrm{SO}_{4}$ concentration. The maximum LA yield of $33 \%$ was attained at $200{ }^{\circ} \mathrm{C}, 8 \% \mathrm{H}_{2} \mathrm{SO}_{4}$ concentration, and $10 \%$ flour loading [40].

Sugar Cane Molasses is a biomass very rich in sucrose, which can be easily hydrolyzed to hexoses, such glucose and fructose. Additionally, Sugar Cane Molasses itself has a slight amount of glucose and fructose in the structure. A recent study [41] proposed a superimposed reaction, in which the LA solution formed from the hexose hydrolysis reaction could be further used as the solvent for additional hexose hydrolysis to produce more LA. First, the optimum condition of reaction was selected as 
$180{ }^{\circ} \mathrm{C}$ for $180 \mathrm{~min} . \mathrm{H}_{2} \mathrm{SO}_{4}$ concentration was one of the critical factors that affected the product distribution. Therefore, a relatively high concentration of $\mathrm{H}_{2} \mathrm{SO}_{4}(0.2 \mathrm{M})$ was used as the catalyst for the following works. An average yield of 30 and $24 \%$ LA was obtained in the third and fifth superimposed reactions, respectively. In addition, a similar biomass (sugar beet molasses) was used in another study for LA formation. The authors suggested an acidic cation exchange resin (Amberlyst-36TM) as the heterogeneous catalyst for this reaction. However, a pretreatment step was performed due to the rapid deactivation of the catalyst for the presence of non-sugar components, such as cations, proteins, and alkaline compounds in the biomass. In order to remove the impurities of the biomass, it was transferred from a column packed with the resin pellets which was also recovered several times under ambient conditions for repeated pretreatment. The highest LA yield of $78 \mathrm{~mol} \%$ was produced in the optimum reaction condition of $0.2 \mathrm{~g} / \mathrm{mL}$ catalyst dosage, $140{ }^{\circ} \mathrm{C}$ and $180 \mathrm{~min}$. [42].

As can be seen in the Table 1, in all of the works, mostly homogeneous catalysts were used for LA production from first generation of biomass. Although these types of catalyst exhibit favorable yields with reasonable cost, they cannot be considered as promising catalysts due to limited recyclability, reactor corrosion, and waste generation [43-45]. These drawbacks can be overcome by using appropriate heterogeneous catalysts instead of homogeneous ones. Therefore, using a cost-effective and environment-friendly catalyst with a reasonable mass transfer, activity, and stability is required.

However, producing fuels and chemicals from edible biomass has become a disputable topic since there are millions people in the world struggling with the challenge of accessing to the sufficient food. In addition, using first generation biomass leads to several challenges, such as negative impact on food security, violations of people's rights and livelihoods by large-scale land acquisition for sourcing biomass, biodiversity and water preservation, and negative impact of biomass plants on local air quality through processing and transport emissions and on the aesthetics of the local landscape. Hence, all of these different challenges regarding using edible biomass cause a focus on developing second generation technologies to produce fuels and chemicals from food waste or nonedible feedstocks [46-49].

Table 1. Valorization of first generation biomass into LA over catalysts.

\begin{tabular}{|c|c|c|c|c|c|c|c|c|}
\hline Biomass & Solvent & Homo Cat & Hetero Cat & Temperature $\left({ }^{\circ} \mathrm{C}\right)$ & Time (min) & Other & $\begin{array}{l}\text { Yield } \\
\text { of LA }\end{array}$ & Ref \\
\hline Normal corn starch & $\mathrm{H}_{2} \mathrm{O}$ & $\mathrm{HCl}$ & - & 165 & 15 & $\mathrm{mw}$ & $53-55 \%$ & [38] \\
\hline $\begin{array}{l}\text { High-amylose } \\
\text { corn starch }\end{array}$ & $\mathrm{H}_{2} \mathrm{O}$ & $\mathrm{HCl}$ & - & 165 & 15 & $\mathrm{mw}$ & $53-55 \%$ & [38] \\
\hline Waxy corn starch & $\mathrm{H}_{2} \mathrm{O}$ & $\mathrm{HCl}$ & - & 165 & 15 & $\mathrm{mw}$ & $53-55 \%$ & [38] \\
\hline kernel sorghum grain & $\mathrm{H}_{2} \mathrm{O}$ & $\mathrm{H}_{2} \mathrm{SO}_{4}$ & - & 200 & 40 & & $33 \%$ & [40] \\
\hline Sugar cane molasses & $\begin{array}{l}\mathrm{H}_{2} \mathrm{O}+ \\
\mathrm{LA}\end{array}$ & $\mathrm{H}_{2} \mathrm{SO}_{4}$ & - & 180 & 180 & & $30 \%$ & [41] \\
\hline Sugar beet molasses & - & - & Amberlyst-36TM & 140 & 180 & PRET & $\begin{array}{c}78 \\
\mathrm{~mol} \%\end{array}$ & [42] \\
\hline
\end{tabular}

\section{LA Production from Second Generation of Biomass: Food Waste and Lignocellulosic Biomass}

Second generation or lignocellulosic biomass consisting hemicellulose and cellulose is one of the most plentiful renewable resources. As can be seen in Figure 5, cellulose can be hydrolysed into glucose by using Brønsted acid as the catalyst that further dehydrates into 5-HMF and then rehydrates into LA catalyzed by Brønsted acid catalyst on the course of lignocellulosic biomass conversion. Besides, hemicellulose can be hydrolyzed into xylose by using Brønsted acid, followed by dehydration of xylose to furfural and hydrogenation of furfural towards furfuryl alcohol and ethyl levulinate and then LA over bifunctional catalysts $[10,13,14,16,17,50-52]$. Lignin is another organic component of lignocelluloses that is linked with hydrogen, chemical, and covalent linkage to cellulose and hemicellulose and packs them densely. Most of the lignin remains as the solid residue through LA formation, and only a slight amount of lignin dissolves in the solution. Lignin can be converted into humins in acidic reaction 
condition and reduce the yield of LA [53]. Pretreatment of actual biomass is one of the prominent methods for isolating cellulose and hemicellulose of biomass from lignin before the hydrolysis. Dilute acid pretreatment is one of the most common methods for biochemical production $[54,55]$.

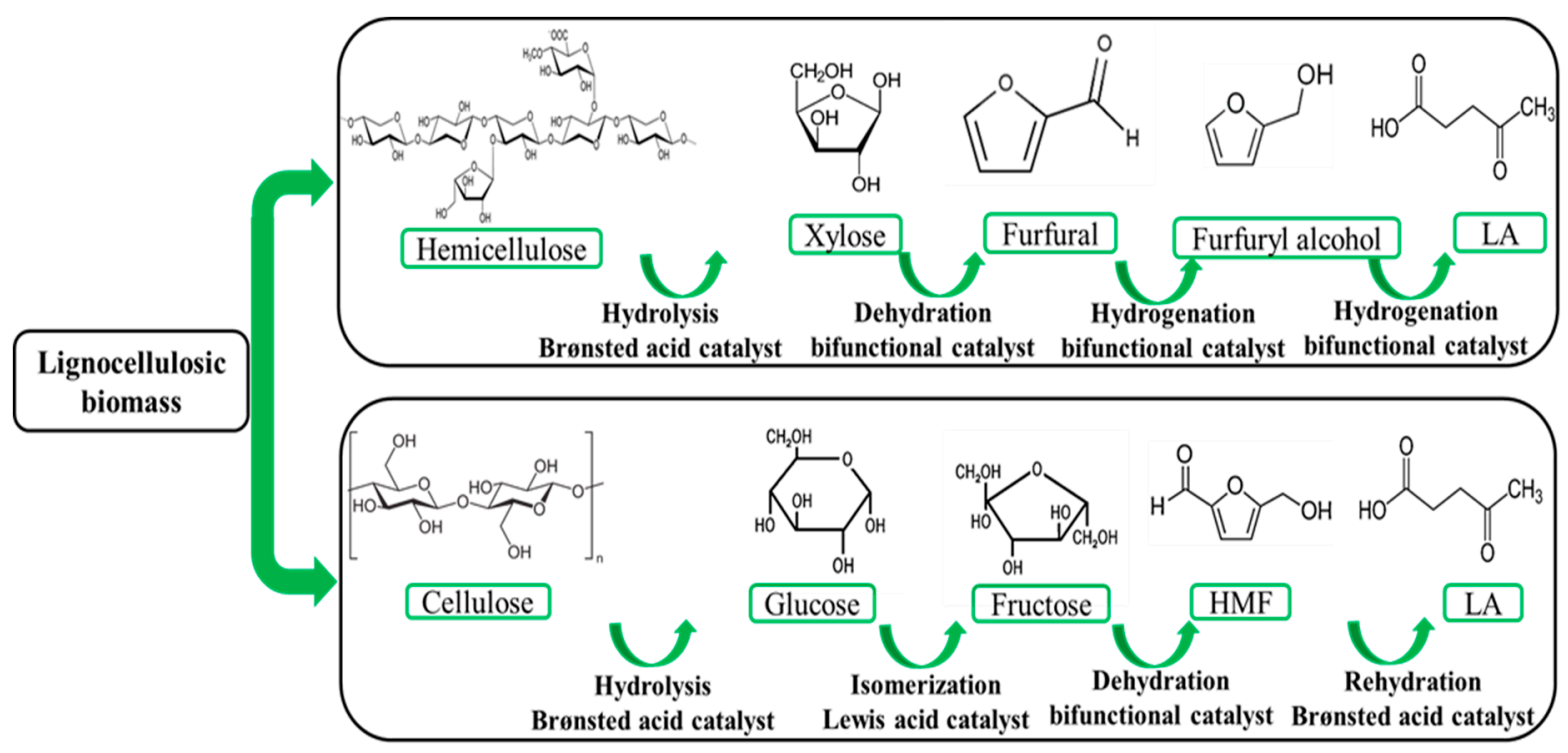

Figure 5. Overview of LA production from second generation biomass.

Several works reported synthesis of LA from different types of straw (rice straw, cotton straw, barley straw, Paddy Straw) by using ionic liquid, homogenous, and heterogeneous catalysts. In 2018, by using Acidic ionic liquid (IL) $\left[\mathrm{C}_{3} \mathrm{SO}_{3} \mathrm{Hmim} \mathrm{HSO}_{4}\right.$ as a catalyst, at $180{ }^{\circ} \mathrm{C}$ and after $30 \mathrm{~min}$. of one pot reaction, yield of $96 \mathrm{~mol} \%(21 \mathrm{wt} \%)$ was obtained from rice straw. It was proven that acidity and hydrogen bonding ability of anions are viable to the yield of LA. In addition, the catalyst was reused over five cycles without any loss of activity [56]. Another work reported an improvement rice straw accessibility to a solid superacid $\mathrm{S}_{2} \mathrm{O}_{8}{ }^{2-} / \mathrm{ZrO}_{2}-\mathrm{SiO}_{2}-\mathrm{Sm}_{2} \mathrm{O}_{3}$ catalyst by using enzymatic pretreatment and phydroxyanisole inhibitor reduced the side reactions during reaction processes, which led to LA yield of 25 wt.\% under the optimal condition [57,58]. Moreover, Ga salt of molybdophosphoric acid, GaHPMo, was found to be a possible alternative to the conventional mineral acids used for the production of LA yield of $46 \mathrm{wt}$ \% from rice straw. GaHPMo exhibited superior catalytic performance in terms of activity for glucose conversion and selectivity for LA production relative to the parent HPMo [59]. As a homogeneous catalyst, $\mathrm{HCl}$ was used as a catalyst during the hydrolysis reaction of straw, because of its low cost and effectiveness. In 2016, a group of authors suggested several chemicals reagents, such as $\mathrm{H}_{2} \mathrm{SO}_{4}, \mathrm{NaOH}, \mathrm{NaClO}_{2}$, and $\mathrm{NaClO}$ for the thermo-chemical pretreatment of rice straw. Subsequently, they performed a post-pretreatment of rice straw fibers for LA formation in a co-solvent reactor system consisting of aqueous $\mathrm{HCl}$, tetrahydrofuran (THF), and Dimethyl sulfoxide (DMSO). The highest LA yield was $21 \%$ by using $\mathrm{H}_{2} \mathrm{SO}_{4}$ as the pretreatment reagent [60]. In 2018, the author provided LA production from rice straw while using a co-solvent biphasic reactor system and $\mathrm{HCl}$ and dichloromethane organic solvent. The author claimed that, beside $\mathrm{HCl}$, the acidic product could catalyze the hydrolysis reaction (auto-catalysis). The optimum yield of LA achieved 15\% wt. in this work [61]. Another study reported that a low concentration of LA does not provide enough $\mathrm{H}^{+}$for hydrolysis of the cellulose and, hence, cause a low reaction rate. On the other hand, too high concentrations lead side reactions, which may negatively affect the rate of hydrolysis of the cellulose to LA. Therefore, by using $\mathrm{HCl}$ with the concentration of $4.45 \%$ in optimum condition of reaction, the maximum yield of $24 \%$ LA was produced from paddy straw [62]. In addition, in some works, a dilute concentration of $\mathrm{H}_{2} \mathrm{SO}_{4}$ was used as a catalyst during hydrolysis reaction. In one of the study, a $9.5 \%$ yield of LA was produced from cotton straw in two-step hydrolysis in the optimum hydrolysis 
condition [63], while in another study $0.03 \mathrm{~g} / \mathrm{L}$ of LA was produced from barley straw in which the $\mathrm{H}_{2} \mathrm{SO}_{4}$ acid improves dissolving hemicellulose fraction of the straw [64].

In 2017, several types of lignocellulosic biomass (palm oil frond, rubber wood, bamboo and rice husk) were converted to LA in one-pot reaction. Dicationic ionic liquids, containing 1,1-Bis(3-methylimidazolium-1-yl) butylene $\left(\left[\mathrm{C}_{4}(\mathrm{Mim})_{2}\right]\right)$ cation with counter anions $\left[\left(2 \mathrm{HSO}_{4}\right)\left(\mathrm{H}_{2} \mathrm{SO}_{4}\right)_{0}\right],\left[\left(2 \mathrm{HSO}_{4}\right)\left(\mathrm{H}_{2} \mathrm{SO}_{4}\right)_{2}\right]$ and $\left[\left(2 \mathrm{HSO}_{4}\right)\left(\mathrm{H}_{2} \mathrm{SO}_{4}\right)_{4}\right]$ were used in different hydrolysis conditions for all types of biomass. However, under optimum experimental condition $\left(100{ }^{\circ} \mathrm{C}\right.$, $60 \mathrm{~min}$.), $\left[\mathrm{C}_{4}(\mathrm{Mim})_{2}\right]\left[\left(2 \mathrm{HSO}_{4}\right)\left(\mathrm{H}_{2} \mathrm{SO}_{4}\right)_{4}\right]$ gave a higher yield of $\mathrm{LA}$ up to 47.52 from bamboo biomass. Thus, the authors concluded that the yield of LA increases with the increase of the number of $\mathrm{HSO}_{4}$ in anion, which leads to an increase in the acidity and decrease in viscosity of IL [65].

Wood is one of the most plentiful biomass resources in the world, consisting of around $40-45 \%$ cellulose and about $20-30 \%$ of hemicellulose; both can be readily hydrolyzed to monomeric sugars and then sugars are appropriate compounds for both energy and chemical production [66]. There are several papers that investigate different woody biomass (eucalyptus wood, red pine wood, poplar branches, grapevine pruning, pine sawdust, aspen, fir, birch wood) hydrolysis with various homogeneous catalysts $\left(\mathrm{HCl}, \mathrm{H}_{2} \mathrm{SO}_{4}\right.$, and $\left.\mathrm{H}_{3} \mathrm{PO}_{4}\right)$ in the several reaction conditions. In 2015, a work proposed the use of methanol as a solvent for LA synthesis from eucalyptus wood chips and by using $\mathrm{H}_{2} \mathrm{SO}_{4}$ catalyst. $90 \mathrm{vol} \%$ methanol solution as the solvent demonstrated great performance in the inhibition of humins production from glucose by a quick reaction with glucose and convert it into LA and methyl levulinate (MLA). Therefore, $66 \mathrm{~mol} \%$ of LA and MLA was produced in best reaction condition at $180^{\circ} \mathrm{C}$ and $90 \mathrm{~min}$. [25]. In 2016, the same authors used the same biomass (eucalyptus wood) and catalyst $\left(\mathrm{H}_{2} \mathrm{SO}_{4}\right)$ to produce LA. First, for xylose recovery from hemicellulose, a pretreatment in the mild conditions was done. Subsequently, the pretreated solution was reused in optimum condition of $170{ }^{\circ} \mathrm{C}$ and $300 \mathrm{~min}$. to produce $105 \mathrm{~g} / \mathrm{L}$ of LA. The authors justified that high concentration of old LA in reaction solution leads to some interaction with other intermediates and byproducts reducing the production of LA from glucose [53]. The conversion of Pinus pinaster wood into LA while using two consecutive treatments with hot, compressed water was also reported. Water-solubles and hemicellulose solubilization were removed in the first and second step pretreatment, respectively. The pretreated liquid was mixed with $\mathrm{H}_{2} \mathrm{SO}_{4}$ as the catalyst and hydrolyzed at different acid concentrations, temperatures, and reaction times. $66 \%$ yield of LA was produced in the optimum reaction condition of $135^{\circ} \mathrm{C}$ and $3600 \mathrm{~min}$. [67]. In 2012, another work designed two-step acid-catalytic conversion of hybrid poplar wood chips into LA in order to inhibit humins production from pentose fraction in biomass in severe acid conditions. The reaction was started with a mild acid extraction to remove most of the pentoses and then followed by second harsher step by using a high concentration of $\mathrm{H}_{2} \mathrm{SO}_{4}$ as a catalyst to convert the first step extracted solids to LA. A maximum molar yield of $17.5 \mathrm{wt} \%$ based of the initial biomass was produced in the best reaction condition [68]. Kuznetsov et al., in 2013, studied the LA production from different kinds of wood (aspen, pine, fir, birch) using steam conversion of wood impregnated with $\mathrm{H}_{2} \mathrm{SO}_{4}(5 \mathrm{wt} \%$ ) as a catalyst at $220{ }^{\circ} \mathrm{C}$ for $120 \mathrm{~min}$. The highest yield of $24 \% \mathrm{LA}$ from wood was attained in all types of wood. Additionally, the authors mentioned that the ability of inorganic acids as a catalyst to hydrolyze carbohydrate into LA could be considered in the following activity order: $\mathrm{HCl}>\mathrm{H}_{2} \mathrm{SO}_{4}>\mathrm{H}_{3} \mathrm{PO}_{4}$ [69].

There are several studies focusing on corn stalk, corn cob residue, and corn stover as a biomass for LA production. In 2015, $\mathrm{FeCl}_{3}$ solution was proven as a catalyst for the synthesis of LA from corn stalk. $\mathrm{FeCl}_{3}$ solution played a positive role in LA production in high temperature and concentration. The highest LA yield was produced at $48.7 \%$ under the optimum condition of $230{ }^{\circ} \mathrm{C}$ and $10 \mathrm{~min}$. with $0.5 \mathrm{~mol} / \mathrm{L} \mathrm{FeCl}_{3}$ solution [70]. Another study reported a high yield of LA (70\%) from corn stover. First, biomass was loaded to an enzymatic saccharification step for glucose production and also isomerization of glucose to fructose. Subsequently, fructose conversion to LA was performed in an effective mixture of acidic ionic liquid $\left[\mathrm{BMIMSO}_{3} \mathrm{H}\right] \mathrm{HSO}_{4}$ and $\mathrm{DI}$ water without any extra need for an acid catalyst [71]. A new fed-batch process for increasing the concentration of LA produced from corncob residues in $\mathrm{H}_{2} \mathrm{SO}_{4}$ solution was recently designed by Liang et al. The fed-batch process 
(seven stage) was performed after a pretreatment in $3 \mathrm{wt} . \% \mathrm{H}_{2} \mathrm{SO}_{4}$ solution to remove the hemicellulose from corncobs. The mass concentration of LA was raised from $23.6 \mathrm{~g} / \mathrm{L}$ to $107.9 \mathrm{~g} / \mathrm{L}$ after first and seventh hydrolysis, respectively. The authors claimed that this new process led to a decrease in the amount of acid catalyst in the reaction and a reduction of energy consumption. Additionally, they found that LA yield during the fed-batch process was dropped, owing to the polymerization of the 5-HMF and the glucose to soluble humins analogues [72]. An efficient homogenous catalyst was used for the production of LA from corncob residue by Zhao et al. Using $\mathrm{SnCl}_{4}$ as the catalyst was led to $64.6 \mathrm{~mol} \%$ yield of LA at $180{ }^{\circ} \mathrm{C}$ after $60 \mathrm{~min}$. The authors demonstrated that, after hydrolysis of $\mathrm{SnCl}_{4}$ catalyst in water, stannic oxide, $\mathrm{H}^{+}$, and $\mathrm{Cl}^{-}$could be produced. Therefore, cellulose hydrolysis was catalyzed by $\mathrm{Cl}^{-}$and $\mathrm{H}^{+}$, fructose dehydration and 5-HMF decomposition were improved by $\mathrm{H}^{+}$as Brønsted acid, both glucose-to-fructose isomerization and fructose consumption yielding undesirable polymers were catalyzed by $\mathrm{Sn}(\mathrm{IV})$ species when considering that it can have some negative impact on cellulose hydrolysis [73]. Furthermore, corncob was used as the raw biomass for LA production that was catalyzed with acid modified zeolite as a heterogeneous catalyst in subcritical condition. The natural zeolite was modified while using a different ratio of $\mathrm{HCl}$ solution. By increasing the ratio of $\mathrm{HCl}$ in zeolite, the $\mathrm{H}^{+}$ion increased in the surface of zeolite and subsequently in reaction solution improving the hydrolysis of cellulose and hemicellulose to produce monomeric sugars. Additionally, acidic condition and high temperature boosted the dehydration of monomeric sugars to LA. The highest yield of LA was $262 \mathrm{mg} / \mathrm{g}$ obtained at $200{ }^{\circ} \mathrm{C}$ during a reaction time of $60 \mathrm{~min}$., and zeolite to acid ratio of 1:15. In addition, this catalyst indicated a gradual deactivation and an acceptable stability and reusability after five cycles [74].

Sugarcane bagasse, in several countries, is produced in a vast amount as by-products of agro-industrial production. In addition, this type of biomass is potentially prone in LA production with a relatively lower market price. Two studies proposed the use of sugarcane bagasse as a feedstock for LA production. In 2013, 63\% LA was directly produced by using $0.55 \mathrm{M} \mathrm{H}_{2} \mathrm{SO}_{4}$ as the catalyst in the optimum condition of $150{ }^{\circ} \mathrm{C}$ and $360 \mathrm{~min}$. [75]. In 2017, first, a pretreatment of Sugarcane bagasse with $\mathrm{H}_{2} \mathrm{SO}_{4}$ acid at $120{ }^{\circ} \mathrm{C}$ and delignification with $\mathrm{NaOH}$ alkali at $80{ }^{\circ} \mathrm{C}$ were performed. Afterwards, an acid hydrolysis carried out in different condition. The highest LA yield of $55.00 \pm 0.36 \%$ was produced at $170{ }^{\circ} \mathrm{C}$ and $75 \mathrm{~min}$. with the presence of $\mathrm{H}_{2} \mathrm{SO}_{4}$ as the reaction catalyst [76].

Jeong et al., demonstrated the application of Quercus mongolica as a biomass for LA production. They suggested a pretreatment by using $\mathrm{H}_{2} \mathrm{SO}_{4}$ dilute acid at $150{ }^{\circ} \mathrm{C}$ in $10 \mathrm{~min}$. After this acid-catalyzed pretreatment, the liquid hydrolysate was rich of the hemicellulosic $\mathrm{C}_{5}$ sugars, whereas the solid fraction contained the $\mathrm{C}_{6}$ sugars. In 2017, they used the solid fraction for second step acid-catalyzed treatment by using $\mathrm{H}_{2} \mathrm{SO}_{4}$ as the homogeneous catalyst. The highest LA yield of $16.5 \%$ ( $\mathrm{g} / 100 \mathrm{~g}$ biomass) was produced in the optimum condition [77]. On the other hand, in 2018, they used the liquid hydrolysate for catalytic conversion of $C_{5}$ sugar to LA by using the heterogeneous catalyst of alkaline-treated zeolites Y (commercial). The maximum yield of $4.6 \% \mathrm{LA}$ was produced at $190{ }^{\circ} \mathrm{C}$ and $180 \mathrm{~min}$. [78].

In 2012, a study proposed the use of a hybrid catalyst made of $\mathrm{HY}$ zeolite and $\mathrm{CrCl}_{3}$ in one pot conversion of empty fruit bunch and kenaf to LA. The author claimed that the catalytic reaction of the catalysts was predominantly influenced by the type of acid sites (Lewis acid), acid sites density, pore size, and shape selectivity. Hydrolysis of empty fruit bunch and kenaf at optimum temperature of $145^{\circ} \mathrm{C}$ and reaction time of $146 \mathrm{~min}$. produced $53 \%$ and $66 \%$ of the LA, respectively. This high yield of LA was justified by the suitable acidity of catalyst, the sufficient microspores and mesoporous diameter to decrease some side reactions (fragmentation and polymerization), and proper shape selectivity, which leads to trap 5-HMF (intermediate product of glucose) within the cage and rehydrate by acid sites to form LA [79]. In addition, using metal halide $\left(\mathrm{CrCl}_{3}\right)$ beside zeolite demonstrated great catalytic reactivity by improving the $\mathrm{LA}$ yield. $\mathrm{CrCl}_{3}$ as a Lewis acid site promoted the glucose isomerization, whereas both Brønsted and Lewis acid sites of $\mathrm{CrCl}_{3}$ and zeolite improved the dehydration/rehydration reaction to $\mathrm{LA}$. 
In 2017, the oil palm fronds were transferred into LA while using an acidic ionic liquid 1-sulfonic acid-3-methyl imidazolium tetrachloroferrate ([SMIM] $\left.\left[\mathrm{FeCl}_{4}\right]\right)$ as the catalyst. Two important properties of ionic liquid for biomass dissolution and high acidity to catalyze the overall reaction made [SMIM] $\left[\mathrm{FeCl}_{4}\right]$ a potential catalyst for direct conversion of oil palm fronds into LA. The optimum yield of $25 \%$ was produced at $154.5^{\circ} \mathrm{C}$ during $3.7 \mathrm{~h}$ of reaction time [80].

In 2017, Tiong et al., proposed a heterogeneous catalyst that was made of indium trichloride as the Lewis acidic site and a noncorrosive ionic liquid, 1-methylimidazolium hydrogen sulfate as the Brønsted acidic site to produce LA from oil palm empty fruit bunch and mesocarp fiber biomass. The authors suggested that the concentration of catalyst is one of the most important factors in the depolarization of biomass, because the excess loading of catalyst causes cross polymerization, acceleration of the reducing sugars degradation, and the production of black insoluble charred materials, the so-called "humins". Furthermore, the presence of $\mathrm{InCl}_{3}$ as the Lewis acid helped the production of desirable product by promotion of glucose to fructose isomerization. The best result was $12 \%$ and $13 \%$ yield of LA conducted at ionic liquids-to-biomass ratio of $5: 1(w / w), 0.15 \mathrm{mmol} \mathrm{InCl}_{3}$, and temperature of $160^{\circ} \mathrm{C}$ for $300 \mathrm{~min}$. from oil palm empty fruit bunch and mesocarp fiber, respectively [81]. In 2019, the same authors used the same catalyst and biomass feedstock in order to optimize the operation condition by the response surface methodology approach. The best result, including LA yield of almost $18 \%$, was obtained at $177^{\circ} \mathrm{C}$ in $288 \mathrm{~min}$. with $0.15 \mathrm{mmol} \mathrm{InCl}_{3}$ in ionic liquids-to-biomass ratio of $6.6: 1(\mathrm{w} / \mathrm{w})$ from both oil palm empty fruit bunch and mesocarp fiber biomass [82].

It has been reported that giant reed as a suitable biomass in the Mediterranean area growing under extreme conditions can be directly convert to LA with a maximum yield of $23 \%$. First, when pre-treatment of the biomass was needed, it was performed at a lower temperature for $120 \mathrm{~min}$. Subsequently, the main hydrothermal conversion was accomplished by using $\mathrm{HCl}$ as an appropriate homogeneous acid catalyst. The authors believed that $\mathrm{HCl}$ could have a great performance, even at low concentration [83]. In 2015, the same authors tried to optimize the reaction condition by using microwave heating method and also the diluted acid approach. Eventually, the maximum LA yield of $21 \%$ was obtained at $180^{\circ} \mathrm{C}$ for $20 \mathrm{~min}$. [84].

The microwave heating process was also used for the conversion of two types of biomass, including carbohydrate-rich potato peel waste and sporocarps of the fungus Cortinarius armillatus to LA. The reaction was performed in the presence of both Brønsted acid $\left(\mathrm{H}_{2} \mathrm{SO}_{4}\right)$ and Lewis acid $\left(\mathrm{CrCl}_{3} \cdot 6 \mathrm{H}_{2} \mathrm{O}\right.$ or $\left.\mathrm{AlCl}_{3} \cdot 6 \mathrm{H}_{2} \mathrm{O}\right)$ catalysts. The authors reported that the process was dependent on the time, temperature, $\mathrm{H}_{2} \mathrm{SO}_{4}$, and Lewis acid concentrations. The maximum LA yield of $49 \%$ and $62 \%$ was achieved in the optimum reaction conditions of $180^{\circ} \mathrm{C}, 15 \mathrm{~min}$. and $180^{\circ} \mathrm{C}, 40 \mathrm{~min}$. from potato peel waste and Cortinarius armillatus, respectively [85]. Since the solid heterogeneous catalyst has polarity, it can interact with the microwave field and be heated quickly beside the liquid homogeneous catalyst. Thus, the microwave method can be efficient for the reaction due to great thermal influence.

In 2013, bamboo shoot shell was transferred into LA that was catalyzed with ionic liquid $\left[\mathrm{C}_{4} \mathrm{mim}\right] \mathrm{HSO}_{4}$. Although this ionic liquid can be considered to be an effective and environmentally friendly catalyst, when considering their high cost, the authors suggested further investigation of ionic liquids for this application. After optimizing the reaction condition, the best LA yield of $71 \mathrm{~mol} \%$ was obtained at $145^{\circ} \mathrm{C}$ for $104 \mathrm{~min}$. [86].

$\mathrm{HCl}$ and $\mathrm{H}_{2} \mathrm{SO}_{4}$ are the mineral acid catalysts that were used for the conversion of biomass to LA in the most of the works, as it is obvious from Table 2. Using these homogenous catalysts that are as the common and traditional catalysts for decades allowing for reasonable yield to LA, cost, and easier accessibility. The reactivity of mineral catalysts is related to several prominent factors, such as the strength and concentration of the catalyst, nature and concentration of biomass, and reaction condition, such as time and temperature. 
Table 2. Valorization of second generation biomass into LA over catalysts.

\begin{tabular}{|c|c|c|c|c|c|c|c|c|c|}
\hline Biomass & Solvent & Ionic Liquid & Homo Cat & Hetero Cat & $\mathrm{T}\left({ }^{\circ} \mathrm{C}\right)$ & Time (min) & Other & Yield of LA & Ref \\
\hline Rice straw & $\mathrm{H}_{2} \mathrm{O}$ & \multirow[t]{9}{*}[\mathrm{C}_{3}\mathrm{SO}_{3}\mathrm{Hmim}]{$\mathrm{HSO}_{4}$} & - & - & 180 & 30 & \multirow{4}{*}{ ENZ PRET } & $21 \%$ & [56] \\
\hline Rice straw & $\mathrm{H}_{2} \mathrm{O}$ & & - & $\mathrm{S}_{2} \mathrm{O}_{8}{ }^{2-} / \mathrm{ZrO}^{2}-\mathrm{SiO}_{2}-\mathrm{Sm}_{2} \mathrm{O}_{3}$ & 200 & 10 & & $22 \%$ & [57] \\
\hline Rice straw & $\mathrm{H}_{2} \mathrm{O}$ & & - & $\mathrm{S}_{2} \mathrm{O}_{8}{ }^{2-} / \mathrm{ZrO}^{2-} \mathrm{SiO}_{2}-\mathrm{Sm}_{2} \mathrm{O}_{3}$ & 200 & 15 & & $25 \%$ & [58] \\
\hline Rice straw & $\mathrm{H}_{2} \mathrm{O}$ & & - & GaHPMo & 175 & 360 & & $46 \%$ & [59] \\
\hline Rice straw & $\begin{array}{l}\mathrm{H}_{2} \mathrm{O}+\mathrm{THF} \\
+\mathrm{DMSO}\end{array}$ & & $\mathrm{HCl}$ & - & 180 & 120 & \multirow[t]{6}{*}{ PRET $\mathrm{H}_{2} \mathrm{SO}_{4}$} & $21 \%$ & {$[60]$} \\
\hline Rice straw & $\mathrm{H}_{2} \mathrm{O}+\mathrm{DCM}$ & & $\mathrm{HCl}$, FA, LA & - & 200 & 180 & & $16.6 \%$ & [61] \\
\hline Paddy Straw & $\mathrm{H}_{2} \mathrm{O}$ & & $\mathrm{HCl}$ & - & 220 & 45 & & $24 \%$ & [62] \\
\hline Cotton straw & $\mathrm{H}_{2} \mathrm{O}$ & & $\mathrm{H}_{2} \mathrm{SO}_{4}$ & - & 180 & 60 & & $9.5 \%$ & [63] \\
\hline Barley straw & $\mathrm{H}_{2} \mathrm{O}$ & & $\mathrm{H}_{2} \mathrm{SO}_{4}$ & - & 158 & 15 & & $0.03 \mathrm{~g} / \mathrm{L}$ & [64] \\
\hline Bamboo & $\mathrm{H}_{2} \mathrm{O}$ & \multirow[t]{7}{*}[\mathrm{C}_{4}(\mathrm{Mim})_{2}]{$\left[\left(2 \mathrm{HSO}_{4}\right)\left(\mathrm{H}_{2} \mathrm{SO}_{4}\right)_{4}\right]$} & - & - & 100 & 60 & & $47.5 \%$ & [65] \\
\hline Eucalyptus wood chips & $\begin{array}{l}\mathrm{H}_{2} \mathrm{O}+ \\
\mathrm{MeOH}\end{array}$ & & $\mathrm{H}_{2} \mathrm{SO}_{4}$ & - & 180 & 90 & & $66 \mathrm{~mol} \%$ & [25] \\
\hline Eucalyptus wood & $\mathrm{H}_{2} \mathrm{O}$ & & $\mathrm{H}_{2} \mathrm{SO}_{4}$ & - & 170 & 300 & PRET & $105 \mathrm{~g} / \mathrm{L}$ & [53] \\
\hline Pinus pinaster wood & $\mathrm{H}_{2} \mathrm{O}$ & & $\mathrm{H}_{2} \mathrm{SO}_{4}$ & - & 135 & 600 & & $66 \%$ & [67] \\
\hline Poplar wood chips & $\mathrm{H}_{2} \mathrm{O}$ & & $\mathrm{H}_{2} \mathrm{SO}_{4}$ & - & 190 & 50 & & $17.8 \%$ & [68] \\
\hline Aspen, pine, fir, birch wood & $\mathrm{H}_{2} \mathrm{O}$ & & $\mathrm{H}_{2} \mathrm{SO}_{4}$ & - & 220 & 120 & & $24 \%$ & [69] \\
\hline Corn stalk & $\mathrm{H}_{2} \mathrm{O}$ & & $\mathrm{FeCl}_{3}$ & - & 230 & 10 & & $48.7 \%$ & [70] \\
\hline Corn Stover & $\mathrm{H}_{2} \mathrm{O}$ & \multirow[t]{10}{*}[\mathrm{BMIMSO}_{3}\mathrm{H}]{$\mathrm{HSO}_{4}$} & - & - & 95 & 60 & & $70 \%$ & [71] \\
\hline Corncob residues & $\mathrm{H}_{2} \mathrm{O}$ & & $\mathrm{H}_{2} \mathrm{SO}_{4}$ & - & 180 & 50 & \multirow{4}{*}{ 7StageH } & $107.9 \mathrm{~g} / \mathrm{L}$ & [72] \\
\hline Corncob residues & $\mathrm{H}_{2} \mathrm{O}$ & & $\mathrm{SnCl}_{4}$ & - & 180 & 60 & & $64.6 \mathrm{~mol} \%$ & [73] \\
\hline Corncob & $\mathrm{H}_{2} \mathrm{O}$ & & - & Acid modified zeolite & 200 & 60 & & $52.48 \mathrm{ppm}$ & [74] \\
\hline Sugarcane bagasse & $\mathrm{H}_{2} \mathrm{O}$ & & $\mathrm{H}_{2} \mathrm{SO}_{4}$ & - & 150 & 360 & & $63 \mathrm{~mol} \%$ & {$[75]$} \\
\hline Sugarcane bagasse & $\mathrm{H}_{2} \mathrm{O}$ & & $\mathrm{H}_{2} \mathrm{SO}_{4}$ & - & 170 & 75 & $\begin{array}{l}\mathrm{PRET} \mathrm{H}_{2} \mathrm{SO}_{4} \\
\mathrm{NaOH}\end{array}$ & $55.00 \pm 0.36 \%$ & {$[76]$} \\
\hline Quercus mongolica & $\mathrm{H}_{2} \mathrm{O}$ & & $\mathrm{H}_{2} \mathrm{SO}_{4}$ & - & 200 & 10 & PRET $\mathrm{H}_{2} \mathrm{SO}_{4}$ & $16.5 \%$ (g/100 g biomass) & [77] \\
\hline Quercus mongolica & $\mathrm{H}_{2} \mathrm{O}$ & & - & modified zeolite $Y$ & 190 & 180 & \multirow[t]{8}{*}{ PRET $\mathrm{H}_{2} \mathrm{SO}_{4}$} & $4.6 \%$ & [78] \\
\hline Empty fruit bunch & $\mathrm{H}_{2} \mathrm{O}$ & & - & hybrid of $\mathrm{HY}$ zeolite and $\mathrm{CrCl}_{3}$ & 145 & 146 & & $53 \%$ & [79] \\
\hline Kenaf & $\mathrm{H}_{2} \mathrm{O}$ & & - & hybrid of $\mathrm{HY}$ zeolite and $\mathrm{CrCl}_{3}$ & 145.2 & 146.7 & & $66 \%$ & [79] \\
\hline Oil palm fronds & $\mathrm{H}_{2} \mathrm{O}$ & {$[\mathrm{SMIM}]\left[\mathrm{FeCl}_{4}\right]$} & - & - & 154.5 & 222 & & $25 \%$ & [80] \\
\hline Oil palm empty fruit bunch & $\mathrm{H}_{2} \mathrm{O}$ & $\mathrm{InCl}_{3}{ }^{-}[\mathrm{HMIM}]\left[\mathrm{HSO}_{4}\right]$ & - & - & 160 & 300 & & $12 \%$ & [81] \\
\hline Mesocarp fiber & $\mathrm{H}_{2} \mathrm{O}$ & $\mathrm{InCl}_{3}^{-}[\mathrm{HMIM}]\left[\mathrm{HSO}_{4}\right]$ & - & - & 160 & 300 & & $13 \%$ & [81] \\
\hline Oil palm empty fruit bunch & $\mathrm{H}_{2} \mathrm{O}$ & $\mathrm{InCl}_{3}{ }^{-}[\mathrm{HMIM}]\left[\mathrm{HSO}_{4}\right]$ & - & - & 177 & 288 & & $17.7 \%$ & [82] \\
\hline Mesocarp fiber & $\mathrm{H}_{2} \mathrm{O}$ & \multirow{5}{*}{$\mathrm{InCl}_{3}{ }^{-}[\mathrm{HMIM}]\left[\mathrm{HSO}_{4}\right]$} & - & - & 177 & 288 & & $18.4 \%$ & [82] \\
\hline Giant reed & $\mathrm{H}_{2} \mathrm{O}$ & & $\mathrm{HCl}$ & - & 180 & 60 & \multirow{2}{*}{$\begin{array}{c}\text { PRET } \\
\text { mw }\end{array}$} & $23 \%$ & [83] \\
\hline Giant reed & $\mathrm{H}_{2} \mathrm{O}$ & & $\mathrm{HCl}$ & - & 180 & 20 & & $21 \%$ & [84] \\
\hline $\begin{array}{l}\text { Carbohydrate-rich potato } \\
\text { peel waste }\end{array}$ & $\mathrm{H}_{2} \mathrm{O}$ & & $\mathrm{H}_{2} \mathrm{SO}_{4}$ & $\mathrm{CrCl}_{3}$ or $\mathrm{AlCl}_{3}$ & 180 & 15 & $\mathrm{mw}$ & $49 \%$ & [85] \\
\hline $\begin{array}{c}\text { Fungus Cortinarius } \\
\text { armillatus }\end{array}$ & $\mathrm{H}_{2} \mathrm{O}$ & & $\mathrm{H}_{2} \mathrm{SO}_{4}$ & $\mathrm{CrCl}_{3}$ or $\mathrm{AlCl}_{3}$ & 180 & 40 & $\mathrm{mw}$ & $62 \%$ & [85] \\
\hline Bamboo shoot shell & $\mathrm{H}_{2} \mathrm{O}$ & {$\left[\mathrm{C}_{4} \mathrm{mim}\right] \mathrm{HSO}_{4}$} & - & - & 145 & 104 & & $71 \mathrm{~mol} \%$ & [86] \\
\hline
\end{tabular}

Homo Cat $=$ Homogenous Catalyst; Hetero Cat $=$ Heterogeneous Catalyst; PRET = PRETREATMENT; ENZ = ENZYMATIC; 7StageH = 7 Stage HYDROLYSIS; mw = microwaves. 
In addition, metal salts, such as different metal chlorides, demonstrated remarkable catalytic activity with higher yield of LA. In this group of catalysts, metal cations can act as the Lewis acid site and intrinsic Brønsted acidity derives from their hydrolysis.

In fact, limited mass transfer of solid-insoluble-substrate/solid-catalyst system causes trouble in using heterogeneous catalysts. Owing to this problem, solid phase catalyst can be more appropriate for water-soluble carbohydrates. There are some few researches that focus on using heterogonous catalysts, especially zeolite with mixed Brønsted and Lewis acid centers in which the results showed an acceptable performance of this group of catalyst.

Moreover, most of the work was performed under an initial and external pressure of an inert gas, such as nitrogen, and the reaction was done in subcritical water. Therefore, the higher pressure of the reaction was produced from high-pressure steam. Water can be a safe and ecofriendly solvent with high thermal conductivity, which can produce ionic product in high temperature and boost the reactivity of the homogeneous catalyst in biomass conversion [87]. However, polysaccharides and biomasses are insoluble in water. The hydrolysis of cellulose to glucose under mild conditions could be a heterogeneous reaction and by using homogeneous catalyst mass transfer is reasonable and the proton of the catalyst can penetrate into the matrix of cellulose [57]. On the other hand, there is limited contact between solid biomass feedstock and solid heterogeneous catalyst while using water as the solvent, and the proton of solid catalyst cannot be widely dispersed in the water solution. To increase the limited mass transfer, using organic solvents, such as THF, DMSO, MIBK, ionic liquids, and biphasic systems (e.g., aqueous/organic solvent, ionic liquids/aqueous) can be efficient [88-91]. Selecting a suitable organic solvent according to the nature of substrate and catalyst is of crucial importance. Some significant factors, such as solubility of feedstock in solvent, having similar polarity of the solvent and feedstock, impact of solvent on selectivity of the desired product, possible recovery and recycling, its expense, and environmental effects must be taken into account.

Some authors used ionic liquid as both solvent and catalyst and the LA yield was low in most cases, depending on the type and reactivity of the ionic liquid. Although this group of solvents attached a great attention due to tunable chemical and physical properties, they demonstrate prominent disadvantages, such as high cost, reactor corrosion, high viscosity and lower mass transfer, and hard recovery by distillation method due to low vapor pressure, which need to be strongly considered. Thus, ionic liquids are not completely environment-friendly and have limitation in using it at the industry level [54,55].

\section{LA Production from Third Generation of Biomass: Algal Biomass}

Recent studies in biofuel and biochemical generation have demonstrated the great potential of macroalgae (seaweed) as the third generation of biomass on extracting high value added chemicals [92]. Macroalgae can be considered as a prominent source of some viable compositions, such as alginates, ulyan, agar, fucoidan, etc. [93,94]. Therefore, polysaccharides are one of the original compositions of three groups of brown, red, and green macroalgae [95]. Using macroalgae as a feedstock for valuable chemicals production has some advantages than second generation biomass consisting no presence of lignin in the structure, high carbohydrate content, and very fast growth rate with the consumption of huge amount of $\mathrm{CO}_{2}[96]$.

The brown seaweeds have some types of carbohydrates consisting of laminaran, mannitol, fucoidan, cellulose, and alginates. Agar, cellulose, xylene, mannan, and carrageenan are the saccharides that are presented in the red seaweed cell wall, whereas the green seaweed cell wall is made up of cellulose, mannose, and xylene [97]. As can be seen in Figure 6, different polysaccharides in macroalgae can be hydrolyzed into monosaccharides, such as glucose, galactose, and xylose by using Brønsted acid as the catalyst. Glucose and galactose are prone to follow the process of dehydration into 5-HMF while using bifunctional catalyst and then rehydration into LA using Brønsted acid catalyst. Furthermore, xylose can be dehydrated into furfural and then hydrogenated into furfuryl alcohol and ethyl levulinate and then LA catalyzed by bifunctional catalysts $[4,98]$. In addition, algal biomass has a considerable 
amount of inorganic salts in the structure, which can act as a contamination and reduce LA yield. Thus, dilute acid pretreatment of this group of biomass is highly recommended, which can lead to the formation of acid salts and remove the metal ions from the biomass body to aqueous solution.

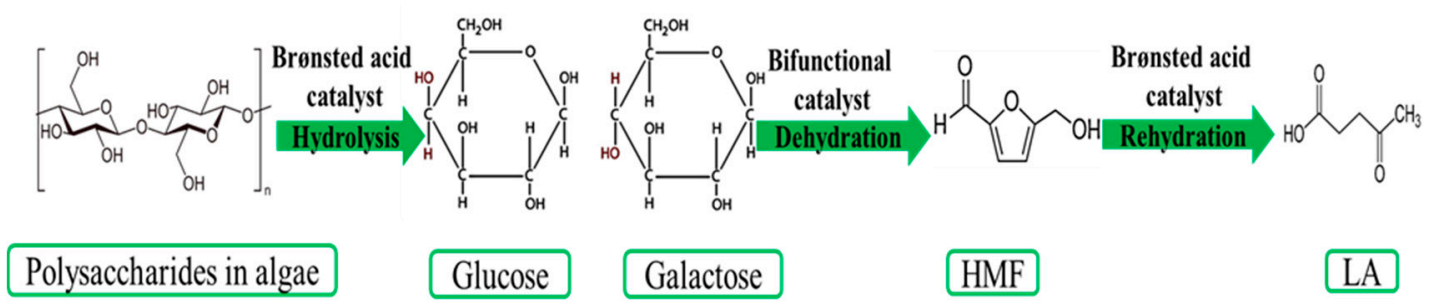

Figure 6. Overview of LA production from third generation biomass.

In 2019, an interesting study has proposed a co-production of LA and hydrochar from red seaweed (Gracilaria lemaneiformis), with high potential for economic viability. The authors selected diluted $\mathrm{H}_{2} \mathrm{SO}_{4}$ as the acid catalyst, because of it being common, effective, and cheap. In addition, it is important to consider the calcium naturally present in biomass because a precipitation reaction between the sulphate ions of the catalyst and calcium might happen. They obtained best LA yield of $16.3 \mathrm{wt} \%$ through microwave treatment under the conditions of $180{ }^{\circ} \mathrm{C}, 20 \mathrm{~min} ., 0.2 \mathrm{M} \mathrm{H}_{2} \mathrm{SO}_{4}$, and $5 \%(w / v)$ of biomass loading [99].

Gracilaria fisheri and Gracilaria. Tenuistipitata as red seaweeds were also transformed into LA after pretreatment at different concentrations of $\mathrm{H}_{2} \mathrm{SO}_{4}$. This work was conducted to examine the pretreatment conditions to boost the production of fermentable sugars and by-products from these biomasses. The catalytic efficiency for both biomasses was higher when the hydrolysis time was $150 \mathrm{~min}$. and at the same time for G. fisheri was higher in comparison with that of G. tenuistipitata. The best LA concentration of $3.66 \mathrm{~g} \mathrm{~L}^{-1}$ and $6.12 \mathrm{~g} \mathrm{~L}^{-1}$ was produced in optimum acid concentration of $1 \mathrm{M} \mathrm{H}_{2} \mathrm{SO}_{4}$ with a reaction time of $150 \mathrm{~min}$. at $95^{\circ} \mathrm{C}$ for $\mathrm{G}$. fisheri and G. tenuistipitata, respectively [100].

In 2015, a study that focused on optimization of reaction condition for conversion of red-algae Gracilaria verrucosa to sugars (glucose, galactose), LA, and 5-HMF by the acidic hydrolysis process. The author reported that LA are prone to being produced at a higher reaction temperature, a higher $\mathrm{H}_{2} \mathrm{SO}_{4}$ catalyst concentration, and a longer reaction time than glucose, galactose or 5-HMF. The best yield of LA was almost $19 \mathrm{wt} \%$ at optimum condition of $180.9{ }^{\circ} \mathrm{C}, 2.85 \%$ acid concentration and $50 \mathrm{~min}$. [101]. In 2018, anothers work reported LA production from the same biomass, but using different type of catalyst. MSA (methanesulfonic acid) was applied as a catalyst to this thermochemical reaction. The author proposed MSA as a stronger, more available and eco-friendly catalyst when compared with other inorganic acids. A LA yield of $22 \%$ was achieved at $180{ }^{\circ} \mathrm{C}, 0.5 \mathrm{M} \mathrm{MSA}$, and $20 \mathrm{~min}$. [102].

In 2010, it has been demonstrated that Gelidium amansii, which is considered as the category of red macroalgae, can also be converted into LA. This seaweed is rich in carbohydrate content (glucose, galactose, galactan, etc.), which is higher than that of lipid, protein, etc. The authors investigated different reaction conditions and found that LA can be produced at a long reaction time, high reaction temperature, and high catalyst concentration. Hence, by using $\mathrm{H}_{2} \mathrm{SO}_{4}$ as the catalyst with concentration of $3.0 \%, 9.7 \mathrm{~g} / \mathrm{L}$ of LA was formed at $160{ }^{\circ} \mathrm{C}$ in $43.1 \mathrm{~min}$. [103]. In 2013, another group of researchers worked on the same biomass for LA formation through two steps hydrolysis process. In the first step, they aimed to optimize the hydrolysis condition to produce higher yield of galactose in the liquor and glucose content in the residue. The optimum condition was selected $\mathrm{H}_{2} \mathrm{SO}_{4}$ concentration of $8.97 \%$, temperature of $76^{\circ} \mathrm{C}$, and reaction time of $49 \mathrm{~h}$. The authors believed that first step pretreatment could be a crucial and viable process for hydrolysis of polysaccharides, such as cellulose into monomers, such as glucose. The second step hydrolysis was performed on higher temperature by using the diluted liquor of first hydrolysis step. The best yield of $43 \% \mathrm{LA}$ was achieved at $180{ }^{\circ} \mathrm{C}, 3 \% \mathrm{H}_{2} \mathrm{SO}_{4}$ concentration, and $48 \mathrm{~min}$. [104]. 
Enteromorpha intestinalis as a green macroalgae were proceeded into fermentable sugars and chemicals. After trying several reaction conditions and their effect on products yield, the authors found that LA could be produced at high temperature, high catalyst concentration, and middling reaction time, although the LA yield was not remarkable. The best LA yield of $4 \%$ was achieved with $\mathrm{H}_{2} \mathrm{SO}_{4}$ concentration of $3.7 \%$ at $175^{\circ} \mathrm{C}$ in $35 \mathrm{~min}$. reaction time [105]. In addition, a group of authors applied another type of green duckweed, Lemna minor, with high starch content of $50 \%$, as the raw material to value-added chemicals production process. First, the process of Duckweed cultivation and induction was performed with the uniconazole-induction method. Subsequently, the cultivated duckweed was proceeded to LA in diluted $\mathrm{HCl}$ aqueous solution in teflon lined stainless steel autoclave. With the enhancement of $\mathrm{HCl}$ concentration, the conversion of the generated glucose into LA and formic acid became faster. The maximum yield of $262 \mathrm{~g} / \mathrm{kg}$ LA was formed at optimum condition of $1.2 \mathrm{w} \% \mathrm{HCl}$, $180^{\circ} \mathrm{C}$ and $150 \mathrm{~min}$. [106].

As can be seen in the Table 3, among different types of macroalgae, red algae have shown to be a better potential on chemicals production, due to the higher content of polysaccharide complexes in the structure. Although homogeneous catalysts are not promising because of limited recyclability, waste generation, and reactor corrosion, all of the studies have been reported on the homogeneous catalytic hydrolysis of third generation biomass into LA. No published data on using heterogeneous catalyst is available. Therefore, the selection of an appropriate heterogeneous catalyst, to be more stable, efficient, green, and recyclable could play a vital role.

Table 3. Valorization of third generation biomass into LA over catalysts.

\begin{tabular}{|c|c|c|c|c|c|c|c|}
\hline Biomass & Solvent & Homogeneous Catalyst & $\mathrm{T}\left({ }^{\circ} \mathrm{C}\right)$ & Time (min) & Other & $\begin{array}{l}\text { Yield } \\
\text { of LA }\end{array}$ & Ref \\
\hline Gracilaria lemaneiformis & $\mathrm{H}_{2} \mathrm{O}$ & $\mathrm{H}_{2} \mathrm{SO}_{4}$ & 180 & 20 & $\mathrm{mw}$ & $16.3 \%$ & [99] \\
\hline Gracilaria fisheri & $\mathrm{H}_{2} \mathrm{O}$ & $\mathrm{H}_{2} \mathrm{SO}_{4}$ & 95 & 150 & & $3.66 \mathrm{~g} \mathrm{~L}^{-1}$ & [100] \\
\hline Gracilaria. tenuistipitata & $\mathrm{H}_{2} \mathrm{O}$ & $\mathrm{H}_{2} \mathrm{SO}_{4}$ & 95 & 150 & & $6.12 \mathrm{~g} \mathrm{~L}^{-1}$ & [100] \\
\hline Gracilaria verrucosa & $\mathrm{H}_{2} \mathrm{O}$ & $\mathrm{H}_{2} \mathrm{SO}_{4}$ & 180.9 & 50 & & $19 \%$ & [101] \\
\hline Gracilaria verrucosa & $\mathrm{H}_{2} \mathrm{O}$ & MSA (methanesulfonic acid) & 180 & 20 & & $22 \%$ & [102] \\
\hline Gelidium amansii & $\mathrm{H}_{2} \mathrm{O}$ & $\mathrm{H}_{2} \mathrm{SO}_{4}$ & 160 & 43.1 & & $9.7 \mathrm{~g} / \mathrm{L}$ & [103] \\
\hline Gelidium amansii & $\mathrm{H}_{2} \mathrm{O}$ & $\mathrm{H}_{2} \mathrm{SO}_{4}$ & 180 & 48 & PRET & $43 \%$ & [104] \\
\hline Enteromorpha intestinalis & $\mathrm{H}_{2} \mathrm{O}$ & $\mathrm{H}_{2} \mathrm{SO}_{4}$ & 175 & 35 & & $4 \%$ & [105] \\
\hline Lemna minor & $\mathrm{H}_{2} \mathrm{O}$ & $\mathrm{HCl}$ & 180 & 150 & & $262 \mathrm{~g} / \mathrm{kg}$ & [106] \\
\hline
\end{tabular}

PRET $=$ PRETREATMENT; $\mathrm{mw}=$ microwaves.

\section{Conclusions}

LA, as an essential chemical building block, can be directly produced from three generation of biomasses. The acid catalyzed reaction pathway of LA production from biomass could be: (i) pretreatment of biomass, (ii) hydrolysis of polysaccharides to monosaccharides, such as hexoses and pentoses, and (iii) conversion of monosaccharides to LA through several step reactions that are dependent on the types of the sugar. Moreover, there are some unavoidable byproducts when the reaction is catalyzed by acid catalyst in which the type of byproducts depends on the type of biomass, catalyst, solvent, and reaction condition. Byproducts can have some negative effects on the hydrolysis efficiency. Three significant outlooks are listed below on the basis of what was discussed through this review:

(1) Pretreatment of biomass seems to be a compulsory step for improving the yield of LA and reaction rate [32]. Some of the studies performed pretreatment before starting real hydrolysis reaction. There are different methods for biomass pretreatment, which depend on the type of the raw starting compounds. Dilute acid pretreatment was demonstrated as the most common method, especially for second generation biomass. Pretreatment causes an increase in cellulose percentage in the feedstock, and most of the glucose could remain in the pretreated feedstock. Therefore, pretreatment could act as a desirable economic method, which leads to higher efficient LA production. According to the type of biomass, it could be more utile if other types of pretreatment, such as mechanical communication, steam explosion, $\mathrm{CO}_{2}$ explosion, pyrolysis, 
organosolv, and biological pretreatment processes are taken into the account in order to remove some destructive components, such as lignin and inorganic salts [107].

(2) Water seems to be a preferable solvent for the LA production from biomass. Water or supercritical water in the reaction condition is safe and environmental friendly. In addition, it has lots of advantages, such as high thermal conductivity and low viscosity. On the other hand, in some cases, water cannot be an appropriate solvent, due to the insolubility of polymeric feedstock, especially when heterogeneous catalyst is used, limited mass transfer and instability of some water-sensitive catalysts, such as metal chloride [108]. Therefore, using the most suitable ionic and organic solvents could be critical. In recent years, study on ionic liquids has attracted great attention, owing their wide performance as solvents as well as catalysts. However, the harmful effect of this class of solvent, such as toxicity, explosivity, biodegradability, and their high cost limits them from plentiful use [109].

(3) According to what was reported in the recent year literatures, homogeneous catalysts, especially $\mathrm{HCl}$ and $\mathrm{H}_{2} \mathrm{SO}_{4}$, were widely used for the conversion of all three generation biomasses. Homogeneous catalysts may be recovered from the reaction solution by using the distillation method, but the challenge of reactor corrosion makes the process outrageously expensive. Replacing homogeneous acid catalysts with green and efficient heterogeneous catalysts can be useful for hydrolysis process in the future. In addition, in recent years, using heterogeneous catalyst in LA production especially from second generation biomass, has gradually increased. Normally, solid catalysts are tunable in the aspect of acidity and reaction condition and they could be easily recovered [110]. Furthermore, heterogeneous catalysts do not have the problem of reactor corrosion and they could be a promising catalyst for industrial use [111]. However, using heterogeneous catalysts still have some limitations, such as limited mass transfer and the deposit of some solid byproducts, such as humins and big organic components on the surface of the catalyst and deactivation over a long period of time.

Furthermore, four outlooks for future trends are highlighted below:

(1) Development of the green heterogeneous catalysts focusing on the important factors, such as surface area, pore size and structure, accessibility of acid sites, recovery and recyclability, and lifetime is the trend for future biomass direct hydrolysis.

(2) Using some novel non-terrestrial resources, such as macroalgae, can demonstrate an important achievement. Therefore, further study is still compulsory for developing an environmental-friendly process with new high recyclable catalysts, which increase the LA yield and progressively target towards raw and cheap biomass feedstock, and finally the possibility to scale up the process going beyond the economic and technological barriers.

(3) Separation and purification of LA from reaction solution, especially while using organic solvent is still a challenge for having a cost-effective application. One potential way to solve this problem is producing a higher LA concentration in the product stream, which can decrease the amount of waste-solvent and reduce the consumption of energy. Moreover, solid acid catalysts are preferred in the separation process. However, work on this research area is still needed.

(4) Formation of by-products, such as thermal-table humins, is still a bottleneck for the industrial scale production of LA. This problem is more relevant while using lignocellulosic biomass (owing to the presence of lignin) as the feedstock. Since humins are prone to blocking and deactivating the catalyst active sites, especially for heterogeneous catalysts, it can limit the scale-up on larger scale. Performing reaction at low temperature, high acid concentration, and using low biomass concentration could be some possible ways of preventing the formation of humins. However, more studies are still needed in order to completely inhibit the formation of humins. In addition, conversion of humins to some new carbon components is suggested for future work. 
Author Contributions: All authors equally contributed to the preparation of this manuscript.

Funding: This research received no external funding.

Conflicts of Interest: The authors declare no conflict of interest.

\section{References}

1. Kang, S.; Fu, J.; Zhang, G. From lignocellulosic biomass to levulinic acid: A review on acid-catalyzed hydrolysis. Renew. Sustain. Energy Rev. 2018, 94, 340-362. [CrossRef]

2. Werpy, T.; Petersen, G. Top Valie Added Chemicals from Biomass: Results of Screening for Potential Candidates from Sugars and Synthesis Gas; Department of Energy: Washington, DC, USA, 2004; pp. 1-76.

3. Boisen, A.; Christensen, T.B.; Fu, W.; Gorbanev, Y.Y.; Hansen, T.S.; Jensen, J.S.; Klitgaard, S.K.; Pedersen, S.; Riisager, A.; Ståhlberg, T.; et al. Process integration for the conversion of glucose to 2, 5-furandicarboxylic acid. Chem. Eng. Res. Des. 2009, 87, 1318-1327. [CrossRef]

4. Mukherjee, A.; Dumont, M.J.; Raghavan, V. Review: Sustainable production of hydroxymethylfurfural and levulinic acid: Challenges and opportunities. Biomass Bioenergy 2015, 72, 143-183. [CrossRef]

5. Zhang, X.; Wilson, K.; Lee, A.F. Heterogeneously Catalyzed Hydrothermal Processing of C5-C6 Sugars. Chem. Rev. 2016, 116, 12328-12368. [CrossRef] [PubMed]

6. Vennestrøm, P.N.R.; Osmundsen, C.M.; Christensen, C.H.; Taarning, E. Beyond petrochemicals: The renewable chemicals industry. Angew. Chem. Int. Ed. 2011, 50, 10502-10509. [CrossRef] [PubMed]

7. Pileidis, F.D.; Titirici, M.M. Levulinic Acid Biorefineries: New Challenges for Efficient Utilization of Biomass. ChemSusChem 2016, 9, 562-582. [CrossRef] [PubMed]

8. Morone, A.; Apte, M.; Pandey, R.A. Levulinic acid production from renewable waste resources: Bottlenecks, potential remedies, advancements and applications. Renew. Sustain. Energy Rev. 2015, 51, 548-565. [CrossRef]

9. Dayma, G.; Halter, F.; Foucher, F.; Togbé, C.; Mounaim-Rousselle, C.; Dagaut, P. Experimental and detailed kinetic modeling study of ethyl pentanoate (Ethyl Valerate) oxidation in a jet stirred reactor and laminar burning velocities in a spherical combustion chamber. Energy Fuels 2012, 26, 4735-4748. [CrossRef]

10. Petrus, L.; Louis, J.; Ayoub, P.M.; Clarke, L.; Price, R.; Gosselink, H.; Lange, J.-P. Valeric Biofuels: A Platform of Cellulosic Transportation Fuels. Angew. Chem. Int. Ed. 2010, 49, 4479-4483.

11. Luo, W.; Deka, U.; Beale, A.M.; Van Eck, E.R.H.; Bruijnincx, P.C.A.; Weckhuysen, B.M. Ruthenium-catalyzed hydrogenation of levulinic acid: Influence of the support and solvent on catalyst selectivity and stability. J. Catal. 2013, 301, 175-186. [CrossRef]

12. Chan-Thaw, C.E.; Marelli, M.; Psaro, R.; Ravasio, N.; Zaccheria, F. New generation biofuels: $\gamma$-Valerolactone into valeric esters in one pot. RSC Adv. 2013, 3, 1302-1306. [CrossRef]

13. Bozell, J.J. Connecting Biomass and Petroleum Processing with a Chemical Bridge an Atomic View of Quantum. Science 2010, 329, 522-523. [CrossRef] [PubMed]

14. Bond, J.Q.; Bond, J.Q.; Alonso, D.M.; Wang, D.; West, R.M.; Dumesic, J.A. Integrated catalytic conversion of $\gamma$-valerolactone to liquid alkenes for transportation fuels. Science 2014, 1110, 1110-1115. [CrossRef] [PubMed]

15. Horváth, I.T.; Mehdi, H.; Fábos, V.; Boda, L.; Mika, L.T. $\gamma$-Valerolactone-a sustainable liquid for energy and carbon-based chemicals. Green Chem. 2008, 10, 238-242. [CrossRef]

16. Pan, T.; Deng, J.; Xu, Q.; Xu, Y.; Guo, Q.X.; Fu, Y. Catalytic conversion of biomass-derived levulinic acid to valerate esters as oxygenated fuels using supported ruthenium catalysts. Green Chem. 2013, 15, 2967-2974. [CrossRef]

17. Wettstein, S.G.; Martin Alonso, D.; Gürbüz, E.I.; Dumesic, J.A. A roadmap for conversion of lignocellulosic biomass to chemicals and fuels. Curr. Opin. Chem. Eng. 2012, 1, 218-224. [CrossRef]

18. Yoshida, R.; Sun, D.; Yamada, Y.; Sato, S.; Hutchings, G.J. Vapor-phase hydrogenation of levulinic acid to $\gamma$-valerolactone over Cu-Ni bimetallic catalysts. Catal. Commun. 2017, 97, 79-82. [CrossRef]

19. Mawhood, R.; Gazis, E.; De Jong, S.; Hoefnagels, R.; Slade, R. Production pathways for renewable jet fuel: A review of commercialization. Biofuels Bioprod. Bioref. 2016, 10, 462-484. [CrossRef]

20. Roy Goswami, S.; Dumont, M.J.; Raghavan, V. Starch to value added biochemicals. Starch Staerke 2016, 68, 274-286. [CrossRef]

21. Yan, K.; Jarvis, C.; Gu, J.; Yan, Y. Production and catalytic transformation of levulinic acid: A platform for speciality chemicals and fuels. Renew. Sustain. Energy Rev. 2015, 51, 986-997. [CrossRef] 
22. Martínez, J.J.; Silva, L.; Rojas, H.A.; Romanelli, G.P.; Santos, L.A.; Ramalho, T.C.; Brijaldo, M.H.; Passos, F.B. Reductive amination of levulinic acid to different pyrrolidones on $\mathrm{Ir} / \mathrm{SiO} 2-\mathrm{SO} 3 \mathrm{H}$ : Elucidation of reaction mechanism. Catal. Today 2017, 296, 118-126. [CrossRef]

23. He, D.; Horváth, I.T. Application of silica-supported Shvo's catalysts for transfer hydrogenation of levulinic acid with formic acid. J. Organomet. Chem. 2017, 847, 263-269. [CrossRef]

24. Wu, G.; Guan, N.; Di, L.; Cao, J.; Song, S.; Yao, S.; Li, L. Heterostructured Ni/NiO composite as a robust catalyst for the hydrogenation of levulinic acid to $\gamma$-valerolactone. Appl. Catal. B Environ. 2017, 217, 115-124.

25. Kang, S.; Yu, J. Effect of Methanol on Formation of Levulinates from Cellulosic Biomass. Ind. Eng. Chem. Res. 2015, 54, 11552-11559. [CrossRef]

26. Dwivedi, A.D.; Gupta, K.; Tyagi, D.; Rai, R.K.; Mobin, S.M.; Singh, S.K. Ruthenium and Formic Acid Based Tandem Catalytic Transformation of Bioderived Furans to Levulinic Acid and Diketones in Water. ChemCatChem 2015, 7, 4050-4058. [CrossRef]

27. Yan, Z.; Lin, L.; Liu, S.; March, R.V.; Re, V.; Recei, M.; June, V. Synthesis of $\gamma$-Valerolactone by Hydrogenation of Biomass-derived Levulinic Acid over Ru/C Catalyst. Energy Fuels 2009, 48, 3853-3858. [CrossRef]

28. Windom, B.C.; Lovestead, T.M.; Mascal, M.; Nikitin, E.B.; Bruno, T.J. Advanced distillation curve analysis on ethyl levulinate as a diesel fuel oxygenate and a hybrid biodiesel fuel. Energy Fuels 2011, 25, 1878-1890. [CrossRef]

29. Girisuta, B. Levulinic Acid from Lignocellulosic Biomass; University of Groningen: Groningen, Holland, 2007; ISBN 1226-086X.

30. Chen, S.S.; Maneerung, T.; Tsang, D.C.W.; Ok, Y.S.; Wang, C.H. Valorization of biomass to hydroxymethylfurfural, levulinic acid, and fatty acid methyl ester by heterogeneous catalysts. Chem. Eng. J. 2017, 328, 246-273. [CrossRef]

31. Hayes, D.J.; Fitzpatrick, S.; Hayes, M.H.B.; Ross, J.R.H. The Biofine Process-Production of Levulinic Acid, Furfural, and Formic Acid from Lignocellulosic Feedstocks, in Biorefineries-Industrial Processes and Products: Status Quo and Future Directions. Biorefineries Ind. Process. Prod. 2006, 1, 139-164.

32. Galia, A.; Schiavo, B.; Antonetti, C.; Galletti, A.M.R.; Interrante, L.; Lessi, M.; Scialdone, O.; Valenti, M.G. Autohydrolysis pretreatment of Arundo donax: A comparison between microwave-assisted batch and fast heating rate flow-through reaction systems. Biotechnol. Biofuels 2015, 8, 1-18. [CrossRef]

33. Zhang, K.; Pei, Z.; Wang, D. Organic solvent pretreatment of lignocellulosic biomass for biofuels and biochemicals: A review. Bioresour. Technol. 2016, 199, 21-33. [CrossRef] [PubMed]

34. Rackemann, B.D.; Doherty, W. A Review on the Production of Levulinic Acid and Furanics from Sugars. Int. Sugar J. 2013, 115, 28-34.

35. Jadhav, H.; Pedersen, C.M.; Sølling, T.; Bols, M. 3-deoxy-glucosone is an intermediate in the formation of furfurals from D-glucose. ChemSusChem 2011, 4, 1049-1051. [CrossRef] [PubMed]

36. Zhang, Y.; Pidko, E.A.; Hensen, E.J.M. Molecular aspects of glucose dehydration by chromium chlorides in ionic liquids. Chem. A Eur. J. 2011, 17, 5281-5288. [CrossRef] [PubMed]

37. Roy Goswami, S.; Dumont, M.J.; Raghavan, V. Microwave Assisted Synthesis of 5-Hydroxymethylfurfural from Starch in $\mathrm{AlCl}_{3} \cdot 6 \mathrm{H}_{2} \mathrm{O} / \mathrm{DMSO} /$ [BMIM] Cl System. Ind. Eng. Chem. Res. 2016, 55, 4473-4481. [CrossRef]

38. Mukherjee, A.; Dumont, M.J. Levulinic Acid Production from Starch Using Microwave and Oil Bath Heating: A Kinetic Modeling Approach. Ind. Eng. Chem. Res. 2016, 55, 8941-8949. [CrossRef]

39. Sweygers, N.; Alewaters, N.; Dewil, R.; Appels, L. Microwave effects in the dilute acid hydrolysis of cellulose to 5-hydroxymethylfurfural. Sci. Rep. 2018, 8, 1-11. [CrossRef]

40. Fang, Q.; Hanna, M.A. Experimental studies for levulinic acid production from whole kernel grain sorghum. Bioresour. Technol. 2002, 81, 187-192. [CrossRef]

41. Kang, S.; Fu, J.; Zhou, N.; Liu, R.; Peng, Z.; Xu, Y. Concentrated Levulinic Acid Production from Sugar Cane Molasses. Energy Fuels 2018, 32, 3526-3531. [CrossRef]

42. Kang, S.; Yu, J. Maintenance of a Highly Active Solid Acid Catalyst in Sugar Beet Molasses for Levulinic Acid Production. Sugar Tech 2018, 20, 182-193. [CrossRef]

43. He, Y.; Hoff, T.C.; Emdadi, L.; Wu, Y.; Bouraima, J.; Liu, D. Catalytic consequences of micropore topology, mesoporosity, and acidity on the hydrolysis of sucrose over zeolite catalysts. Catal. Sci. Technol. 2014, 4, 3064-3073. [CrossRef] 
44. Zhou, L.; Shi, M.; Cai, Q.; Wu, L.; Hu, X.; Yang, X.; Chen, C.; Xu, J. Hydrolysis of hemicellulose catalyzed by hierarchical H-USY zeolites-The role of acidity and pore structure. Microporous Mesoporous Mater. 2013, 169, 54-59. [CrossRef]

45. Pang, Q.; Wang, L.; Yang, H.; Jia, L.; Pan, X.; Qiu, C. Cellulose-derived carbon bearing-Cl and-SO ${ }_{3} \mathrm{H}$ groups as a highly selective catalyst for the hydrolysis of cellulose to glucose. RSC Adv. 2014, 40, 41212-41218. [CrossRef]

46. Murphy, R.; Woods, J.; Black, M.; McManus, M. Global developments in the competition for land from biofuels. Food Policy 2011, 36, S52-S61. [CrossRef]

47. Van Eijck, J.; Romijn, H. Prospects for Jatropha biofuels in Tanzania: An analysis with Strategic Niche Management. Energy Policy 2008, 36, 311-325. [CrossRef]

48. Jefferies, D.; Muñoz, I.; Hodges, J.; King, V.J.; Aldaya, M.; Ercin, A.E.; Milà, I.; Canals, L.; Hoekstra, A.Y. Water footprint and life cycle assessment as approaches to assess potential impacts of products on water consumption. Key learning points from pilot studies on tea and margarine. J. Clean. Prod. 2012, 33, $155-166$. [CrossRef]

49. Van der Horst, D.; Vermeylen, S. Spatial scale and social impacts of biofuel production. Biomass Bioenergy 2011, 35, 2435-2443. [CrossRef]

50. Bohre, A.; Saha, B.; Abu-Omar, M.M. Catalytic Upgrading of 5-Hydroxymethylfurfural to Drop-in Biofuels by Solid Base and Bifunctional Metal-Acid Catalysts. ChemSusChem 2015, 8, 4022-4029. [CrossRef]

51. Morales, M.; Quintero, J.; Conejeros, R.; Aroca, G. Life cycle assessment of lignocellulosic bioethanol: Environmental impacts and energy balance. Renew. Sustain. Energy Rev. 2015, 42, 1349-1361. [CrossRef]

52. Lange, J.P.; Van Der Heide, E.; Van Buijtenen, J.; Price, R. Furfural-A promising platform for lignocellulosic biofuels. ChemSusChem 2012, 5, 150-166. [CrossRef]

53. Kang, S.; Yu, J. An intensified reaction technology for high levulinic acid concentration from lignocellulosic biomass. Biomass Bioenergy 2016, 95, 214-220. [CrossRef]

54. Cozier, M. Business highlights: Collaboration: Bigger and beta. Biofuels Bioprod. Biorefining 2014, 8, 743.

55. Zheng, Y.; Pan, Z.; Zhang, R.; Wang, D. Enzymatic saccharification of dilute acid pretreated saline crops for fermentable sugar production. Appl. Energy 2009, 86, 2459-2465. [CrossRef]

56. Liu, L.; Li, Z.; Hou, W.; Shen, H. Direct conversion of lignocellulose to levulinic acid catalyzed by ionic liquid. Carbohydr. Polym. 2018, 181, 778-784. [CrossRef] [PubMed]

57. Chen, H.; Yu, B.; Jin, S. Production of levulinic acid from steam exploded rice straw via solid superacid, $\mathrm{S}_{2} \mathrm{O}_{8}{ }^{2-} / \mathrm{ZrO}_{2}-\mathrm{SiO}_{2}-\mathrm{Sm}_{2} \mathrm{O}_{3}$. Bioresour. Technol. 2011, 102, 3568-3570. [CrossRef]

58. Ma, L.T.; Zhao, Z.M.; Yu, B.; Chen, H.Z. Enzymatic Pretreatment Coupled with the Addition of p-Hydroxyanisole Increased Levulinic Acid Production from Steam-Exploded Rice Straw Short Fiber. Appl. Biochem. Biotechnol. 2016, 180, 945-953. [CrossRef] [PubMed]

59. Kumar, V.B.; Pulidindi, I.N.; Mishra, R.K.; Gedanken, A. Development of Ga Salt of Molybdophosphoric Acid for Biomass Conversion to Levulinic Acid. Energy Fuels 2016, 30, 10583-10591. [CrossRef]

60. Elumalai, S.; Agarwal, B.; Sangwan, R.S. Thermo-chemical pretreatment of rice straw for further processing for levulinic acid production. Bioresour. Technol. 2016, 218, 232-246. [CrossRef]

61. Kumar, S.; Ahluwalia, V.; Kundu, P.; Sangwan, R.S.; Kansal, S.K.; Runge, T.M.; Elumalai, S. Improved levulinic acid production from agri-residue biomass in biphasic solvent system through synergistic catalytic effect of acid and products. Bioresour. Technol. 2018, 251, 143-150. [CrossRef]

62. Yan, L.; Yang, N.; Pang, H.; Liao, B. Production of levulinic acid from bagasse and paddy straw by liquefaction in the presence of hydrochloride acid. Clean Soil Air Water 2008, 36, 158-163. [CrossRef]

63. Yang, Z.; Kang, H.; Guo, Y.; Zhuang, G.; Bai, Z.; Zhang, H.; Feng, C.; Dong, Y. Dilute-acid conversion of cotton straw to sugars and levulinic acid via 2-stage hydrolysis. Ind. Crops Prod. 2013, 46, 205-209. [CrossRef]

64. Won, K.Y.; Um, B.H.; Kim, S.W.; Oh, K.K. Fractionation of barley straw with dilute sulfuric acid for improving hemicellulose recovery. Korean J. Chem. Eng. 2012, 29, 614-620. [CrossRef]

65. Khan, A.S.; Man, Z.; Bustam, M.A.; Nasrullah, A.; Ullah, Z.; Sarwono, A.; Shah, F.U.; Muhammad, N. Efficient conversion of lignocellulosic biomass to levulinic acid using acidic ionic liquids. Carbohydr. Polym. 2018, 181, 208-214. [CrossRef] [PubMed]

66. Martinez, A.; Rodriguez, M.E.; York, S.W.; Preston, J.F.; Ingram, L.O. Use of UV absorbance to monitor furans in dilute acid hydrolysates of biomass. Biotechnol. Prog. 2000, 16, 637-641. [CrossRef] [PubMed] 
67. Rivas, S.; González-Muñoz, M.J.; Vila, C.; Santos, V.; Parajó, J.C. Manufacture of levulinic acid from pine wood hemicelluloses: A kinetic assessment. Ind. Eng. Chem. Res. 2013, 52, 3951-3957. [CrossRef]

68. Runge, T.; Zhang, C. Two-stage acid-catalyzed conversion of carbohydrates into levulinic acid. Ind. Eng. Chem. Res. 2012, 51, 3265-3270. [CrossRef]

69. Kuznetsov, B.N.; Sharypov, V.I.; Grishechko, L.I.; Celzard, A. Integrated catalytic process for obtaining liquid fuels from renewable lignocellulosic biomass. Kinet. Catal. 2013, 54, 344-352. [CrossRef]

70. Zhi, Z.; Li, N.; Qiao, Y.; Zheng, X.; Wang, H.; Lu, X. Kinetic study of levulinic acid production from corn stalk at relatively high temperature using $\mathrm{FeCl}_{3}$ as catalyst: A simplified model evaluated. Ind. Crops Prod. 2015, 76, 672-680. [CrossRef]

71. Alipour, S.; Omidvarborna, H. Enzymatic and catalytic hybrid method for levulinic acid synthesis from biomass sugars. J. Clean. Prod. 2017, 143, 490-496. [CrossRef]

72. Liang, C.; Hu, Y.; Wang, Y.; Wu, L.; Zhang, W. Production of levulinic acid from corn cob residue in a fed-batch acid hydrolysis process. Process Biochem. 2018, 73, 124-131. [CrossRef]

73. Zhao, P.; Zhou, C.; Li, J.; Xu, S.; Hu, C. Synergistic Effect of Different Species in Stannic Chloride Solution on the Production of Levulinic Acid from Biomass. ACS Sustain. Chem. Eng. 2019, 7, 5176-5183. [CrossRef]

74. Hartono, C.D.; Marlie, K.J.; Putro, J.N.; Soetardjo, F.E.; Ju, Y.H.; Sirodj, D.A.N.; Ismadji, S. Levulinic acid from corncob by subcritical water process. Int. J. Ind. Chem. 2016, 7, 401-409. [CrossRef]

75. Girisuta, B.; Dussan, K.; Haverty, D.; Leahy, J.J.; Hayes, M.H.B. A kinetic study of acid catalysed hydrolysis of sugar cane bagasse to levulinic acid. Chem. Eng. J. 2013, 217, 61-70. [CrossRef]

76. Lopes, E.S.; Dominices, K.M.C.; Lopes, M.S.; Tovar, L.P.; Filho, R.M. A green chemical production: Obtaining levulinic acid from pretreated sugarcane bagasse. Chem. Eng. Trans. 2017, 57, 145-150.

77. Jeong, H.; Jang, S.K.; Hong, C.Y.; Kim, S.H.; Lee, S.Y.; Lee, S.M.; Choi, J.W.; Choi, I.G. Levulinic acid production by two-step acid-catalyzed treatment of Quercus mongolica using dilute sulfuric acid. Bioresour. Technol. 2017, 225, 183-190. [CrossRef] [PubMed]

78. Jeong, H.; Park, S.Y.; Ryu, G.H.; Choi, J.H.; Kim, J.H.; Choi, W.S.; Lee, S.M.; Choi, J.W.; Choi, I.G. Catalytic conversion of hemicellulosic sugars derived from biomass to levulinic acid. Catal. Commun. 2018, 117, $19-25$. [CrossRef]

79. Ya'aini, N.; Amin, N.A.S.; Asmadi, M. Optimization of levulinic acid from lignocellulosic biomass using a new hybrid catalyst. Bioresour. Technol. 2012, 116, 58-65. [CrossRef] [PubMed]

80. Ramli, N.A.S.; Amin, N.A.S. Optimization of Biomass Conversion to Levulinic Acid in Acidic Ionic Liquid and Upgrading of Levulinic Acid to Ethyl Levulinate. Bioenergy Res. 2017, 10, 50-63. [CrossRef]

81. Tiong, Y.W.; Yap, C.L.; Gan, S.; Yap, W.S.P. One-pot conversion of oil palm empty fruit bunch and mesocarp fiber biomass to levulinic acid and upgrading to ethyl levulinate via indium trichloride-ionic liquids. J. Clean. Prod. 2017, 168, 1251-1261. [CrossRef]

82. Tiong, Y.W.; Yap, C.L.; Gan, S.; Yap, W.S.P. Optimisation studies on the conversion of oil palm biomass to levulinic acid and ethyl levulinate via indium trichloride-ionic liquids: A response surface methodology approach. Ind. Crops Prod. 2019, 128, 221-234. [CrossRef]

83. Raspolli Galletti, A.M.; Antonetti, C.; Ribechini, E.; Colombini, M.P.; Nassi o Di Nasso, N.; Bonari, E. From giant reed to levulinic acid and gamma-valerolactone: A high yield catalytic route to valeric biofuels. Appl. Energy 2013, 102, 157-162. [CrossRef]

84. Antonetti, C.; Bonari, E.; Licursi, D.; Di Nasso, N.N.; Galletti, A.M.R.; Cravotto, G.; Chemat, F. Hydrothermal conversion of giant reed to furfural and levulinic acid: Optimization of the process under microwave irradiation and investigation of distinctive agronomic parameters. Molecules 2015, 20, 21232-21353. [CrossRef] [PubMed]

85. Dong, Y.; Lappalainen, K.; Markkola, A.; Rusanen, A.; Wäli, P.; Vogeler, N.; Ruotsalainen, A.L.; Kärkkäinen, J.; Lassi, U.; Niemelä, M. Microwave-assisted conversion of novel biomass materials into levulinic acid. Biomass Convers. Biorefinery 2018, 8, 965-970.

86. Zhou, C.; Yu, X.; Ma, H.; He, R.; Vittayapadung, S. Optimization on the conversion of bamboo shoot shell to levulinic acid with environmentally benign acidic ionic liquid and response surface analysis. Chin. J. Chem. Eng. 2013, 21, 544-550. [CrossRef]

87. Lachos-Perez, D.; Martinez-Jimenez, F.; Rezende, C.A.; Tompsett, G.; Timko, M.; Forster-Carneiro, T. Subcritical water hydrolysis of sugarcane bagasse: An approach on solid residues characterization. J. Supercrit. Fluids 2016, 108, 69-78. [CrossRef] 
88. Pagán-Torres, Y.J.; Wang, T.; Gallo, J.M.R.; Shanks, B.H.; Dumesic, J.A. Production of 5-hydroxymethylfurfural from glucose using a combination of lewis and brønsted acid catalysts in water in a biphasic reactor with an alkylphenol solvent. ACS Catal. 2012, 2, 930-934. [CrossRef]

89. Chidambaram, M.; Bell, A.T. A two-step approach for the catalytic conversion of glucose to 2, 5-dimethylfuran in ionic liquids. Green Chem. 2010, 12, 1253-1262. [CrossRef]

90. Saha, B.; Abu-Omar, M.M. Advances in 5-hydroxymethylfurfural production from biomass in biphasic solvents. Green Chem. 2014, 16, 24-38. [CrossRef]

91. Farrán, A.; Cai, C.; Sandoval, M.; Xu, Y.; Liu, J.; Hernáiz, M.J.; Linhardt, R.J. Green Solvents in Carbohydrate Chemistry: From Raw Materials to Fine Chemicals. Chem. Rev. 2015, 115, 6811-6853. [CrossRef]

92. Yuan, Y.; Macquarrie, D.J. Microwave Assisted Acid Hydrolysis of Brown Seaweed Ascophyllum nodosum for Bioethanol Production and Characterization of Alga Residue. ACS Sustain. Chem. Eng. 2015, 3, 1359-1365. [CrossRef]

93. Guo, X.; Gu, D.; Wang, M.; Huang, Y.; Li, H.; Dong, Y.; Tian, J.; Wang, Y.; Yang, Y. Characterization of active compounds from: Gracilaria lemaneiformis inhibiting the protein tyrosine phosphatase 1B activity. Food Funct. 2017, 8, 3271-3275. [CrossRef] [PubMed]

94. Lin, R.; Cheng, J.; Murphy, J.D. Inhibition of thermochemical treatment on biological hydrogen and methane co-production from algae-derived glucose/glycine. Energy Convers. Manag. 2018, 158, 201-209. [CrossRef]

95. Kwon, O.M.; Kim, D.H.; Kim, S.K.; Jeong, G.T. Production of sugars from macro-algae Gracilaria verrucosa using combined process of citric acid-catalyzed pretreatment and enzymatic hydrolysis. Algal Res. 2016, 13, 293-297. [CrossRef]

96. Wyman, C.E. Ethanol from lignocellulosic biomass: Technology, economics, and opportunities. Bioresour. Technol. 1994, 50, 3-15. [CrossRef]

97. Jambo, S.A.; Abdulla, R.; Mohd Azhar, S.H.; Marbawi, H.; Gansau, J.A.; Ravindra, P. A review on third generation bioethanol feedstock. Renew. Sustain. Energy Rev. 2016, 65, 756-769. [CrossRef]

98. Sweygers, N.; Somers, M.H.; Appels, L. Optimization of hydrothermal conversion of bamboo (Phyllostachys aureosulcata) to levulinic acid via response surface methodology. J. Environ. Manag. 2018, 219, 95-102. [CrossRef] [PubMed]

99. Cao, L.; Yu, I.K.M.; Cho, D.W.; Wang, D.; Tsang, D.C.W.; Zhang, S.; Ding, S.; Wang, L.; Ok, Y.S. Microwave-assisted low-temperature hydrothermal treatment of red seaweed (Gracilaria lemaneiformis) for production of levulinic acid and algae hydrochar. Bioresour. Technol. 2019, 273, 251-258. [CrossRef] [PubMed]

100. Nunraksa, N.; Rattanasansri, S.; Praiboon, J.; Chirapart, A. Proximate composition and the production of fermentable sugars, levulinic acid, and HMF from Gracilaria fisheri and Gracilaria tenuistipitata cultivated in earthen ponds. J. Appl. Phycol. 2019, 31, 683-690. [CrossRef]

101. Jeong, G.T.; Ra, C.H.; Hong, Y.K.; Kim, J.K.; Kong, I.S.; Kim, S.K.; Park, D.H. Conversion of red-algae Gracilaria verrucosa to sugars, levulinic acid and 5-hydroxymethylfurfural. Bioprocess Biosyst. Eng. 2015, 38, $207-217$. [CrossRef] [PubMed]

102. Park, M.R.; Kim, S.K.; Jeong, G.T. Optimization of the levulinic acid production from the red macroalga, Gracilaria verrucosa using methanesulfonic acid. Algal Res. 2018, 31, 116-121. [CrossRef]

103. Jeong, G.T.; Park, D.H. Production of Sugars and Levulinic Acid from Marine Biomass Gelidium amansii. Appl. Biochem. Biotechnol. 2010, 161, 41-52. [CrossRef] [PubMed]

104. Kang, M.; Kim, S.W.; Kim, J.W.; Kim, T.H.; Kim, J.S. Optimization of levulinic acid production from Gelidium amansii. Renew. Energy 2013, 54, 173-179. [CrossRef]

105. Kim, D.H.; Lee, S.B.; Kim, S.K.; Park, D.H.; Jeong, G.T. Optimization and Evaluation of Sugars and Chemicals Production from Green Macro-algae Enteromorpha intestinalis. Bioenergy Res. 2016, 9, 1155-1166. [CrossRef]

106. Liu, C.; Feng, Q.; Yang, J.; Qi, X. Catalytic production of levulinic acid and ethyl levulinate from uniconazole-induced duckweed (Lemna minor). Bioresour. Technol. 2018, 255, 50-57. [CrossRef] [PubMed]

107. Sindhu, R.; Kuttiraja, M.; Binod, P.; Janu, K.U.; Sukumaran, R.K.; Pandey, A. Dilute acid pretreatment and enzymatic saccharification of sugarcane tops for bioethanol production. Bioresour. Technol. 2011, 102, 10915-10921. [CrossRef] [PubMed]

108. Binder, J.B.; Raines, R.T. Simple chemical transformation of lignocellulosic biomass into furans for fuels and chemicals. J. Am. Chem. Soc. 2009, 131, 1979-1985. [CrossRef] 
109. Deetlefs, M.; Seddon, K.R. Assessing the greenness of some typical laboratory ionic liquid preparations. Green Chem. 2010, 12, 17-30. [CrossRef]

110. Tong, X.; Ma, Y.; Li, Y. Biomass into chemicals: Conversion of sugars to furan derivatives by catalytic processes. Appl. Catal. A Gen. 2010, 385, 1-13. [CrossRef]

111. Weingarten, R.; Conner, W.C.; Huber, G.W. Production of levulinic acid from cellulose by hydrothermal decomposition combined with aqueous phase dehydration with a solid acid catalyst. Energy Environ. Sci. 2012, 5, 7559-7574. [CrossRef]

(C) 2019 by the authors. Licensee MDPI, Basel, Switzerland. This article is an open access article distributed under the terms and conditions of the Creative Commons Attribution (CC BY) license (http://creativecommons.org/licenses/by/4.0/). 